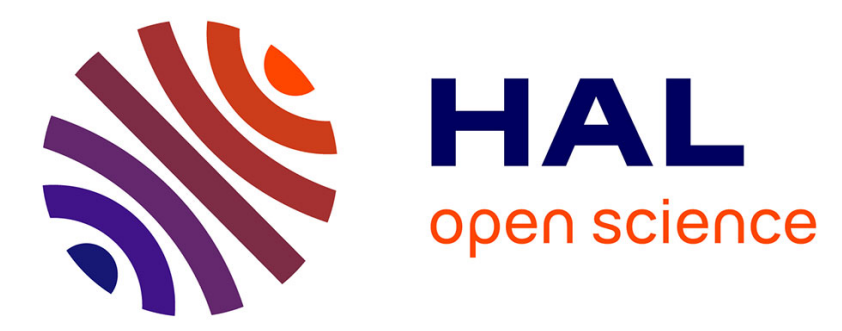

\title{
Introduction of groundwater capillary rises using subgrid spatial variability of topography into the ISBA land surface model
}

J.-P. Vergnes, B. Decharme, Florence Habets

\section{- To cite this version:}

J.-P. Vergnes, B. Decharme, Florence Habets. Introduction of groundwater capillary rises using subgrid spatial variability of topography into the ISBA land surface model. Journal of Geophysical Research: Atmospheres, 2014, 119 (19), pp.11,065-11,086. 10.1002/2014JD021573 . hal-01082536

\section{HAL Id: hal-01082536 \\ https: / hal.sorbonne-universite.fr/hal-01082536}

Submitted on 25 Nov 2021

HAL is a multi-disciplinary open access archive for the deposit and dissemination of scientific research documents, whether they are published or not. The documents may come from teaching and research institutions in France or abroad, or from public or private research centers.
L'archive ouverte pluridisciplinaire HAL, est destinée au dépôt et à la diffusion de documents scientifiques de niveau recherche, publiés ou non, émanant des établissements d'enseignement et de recherche français ou étrangers, des laboratoires publics ou privés.

$$
\text { Copyright }
$$




\section{Journal of Geophysical Research: Atmospheres}

\section{RESEARCH ARTICLE \\ 10.1002/2014JD021573 \\ Key Points: \\ Introduction of groundwater capillary rises using subgrid spatial variability of topography into the ISBA land surface model}

- Upward capillary fluxes from groundwater are simulated in a hydrological model

- Simulated evapotranspiration increases to the detriment of groundwater recharge

- The water table is lowered along with annual mean river discharges

Correspondence to: J.-P. Vergnes,

jpvergnes@gmail.com

\section{Citation:}

Vergnes, J.-P., B. Decharme, and F. Habets (2014), Introduction of groundwater capillary rises using subgrid spatial variability of topography into the ISBA land surface model, J. Geophys. Res. Atmos., 119, 11,065-11,086, doi:10.1002/2014JD021573.

Received 28 JAN 2014 Accepted 6 SEP 2014 Accepted article online 10 SEP 2014 Published online 6 OCT 2014

\author{
J.-P. Vergnes ${ }^{1}$, B. Decharme ${ }^{2}$, and F. Habets ${ }^{1}$ \\ ${ }^{1}$ Sorbonne Universités, UPMC Univ Paris 06, CNRS, UMR 7619, Paris, France, ${ }^{2}$ Météo-France, UMR 3589 CNRM-GAME, \\ Toulouse, France
}

\begin{abstract}
This paper presents a simple method for representing upward capillary fluxes from shallow groundwater into the unsaturated soil column of the large-scale hydrological models generally used at low resolution in global climate models. The groundwater scheme implemented in the Total Runoff Integrating Pathways river-routing model in a previous study is coupled with the Interaction between Soil Biosphere Atmosphere (ISBA) land surface model. In this coupling, the simulated water table depth acts as the lower boundary condition for the soil moisture diffusive equation. An original parameterization accounting for the subgrid topography inside each grid cell is proposed in order to compute this fully coupled soil lower boundary condition. The impact of this coupling on the simulated water budget is evaluated over France for the 1989-2009 period. Simulations are performed at high $\left(1 / 12^{\circ}\right)$ and low $\left(0.5^{\circ}\right)$ resolutions. Upward capillary fluxes induce a decrease in the simulated recharge from ISBA to the aquifers and contributes to an enhancement of the soil moisture memory. The simulated water table depths are then lowered, which induces a slight decrease in the simulated mean annual river discharges. These differences do not affect the comparison with observations. As a consequence, the simulated river discharges and water table heads compare still well with observations for the two soil bottom condition (free drain or fully coupled). It confirms the suitability of the coupling parameterization using subgrid spatial variability of topography. Compared to a free drain experiment, upward capillary fluxes at the bottom of the soil increase the mean annual evapotranspiration simulated over the aquifer domain by $3.12 \%$ and $1.54 \%$ at high and low resolutions, respectively. This increase can locally reach $50 \%$ and $30 \%$, respectively.
\end{abstract}

\section{Introduction}

In climate modeling, land surface hydrology is generally represented by Land Surface Models (LSMs). These models provide the lower boundary conditions of temperature and moisture for atmospheric processes in atmospheric general circulation models. LSMs are generally coupled with a River-Routing Model (RRM) designed to convert the total runoff simulated by LSMs into river discharges in order to transfer the continental fresh water to oceans, thereby closing the water budget of the global hydrological cycle. The simulated river flows can also be compared to observations, thus allowing an assessment of the simulated water budget. However, some processes have yet to be taken into account. In particular, most global climate models do not account for groundwater processes, and only a free drain or no drain soil bottom condition is defined in the LSMs.

The potential impact of groundwater on the water and energy budget simulated at the land surfaceatmosphere interface has been widely studied during the last decade [Salvucci and Entekhabi, 1995; Yeh et al., 1998; Levine and Salvucci, 1999; van den Hurk et al., 2005; Yeh and Eltahir, 2005b; Fan et al., 2007; Decharme et al., 2010]. Groundwater helps to sustain river base flow in humid climates during dry periods through its slow response time, while it receives river seepage in arid climates. The upward capillary fluxes from shallow groundwater to the overlying rooting zone of the soil are likely to impact the soil moisture in unsaturated zones and thus the water and energy budgets at the interface between the surface and the lower atmosphere [York et al., 2002; Miguez-Macho et al., 2007; Sánchez-Pérez et al., 2008; Jiang et al., 2009; Maxwell et al., 2010; Guillot, 2011]. A lack of persistence is also found in the land surface parameterization of climate models [van den Hurk et al., 2005; Fan et al., 2007; Lam et al., 2011]. For example, by analyzing a large database of water table observations over the United States, Fan et al. [2007] demonstrated that the groundwater reservoir has the potential to increase soil moisture memory. More recently, Lam et al. [2011] pointed out that 
groundwater is a source of dry season evaporation, as it introduces a memory effect in land surface processing. This groundwater memory could also impact other components of the climate system, such as temperature [Syroka and Toumi, 2001], precipitation [Bierkens and van den Hurk, 2007], and extreme weather events [Weisheimer et al., 2011]. At last, Lyon et al. [2008] underlines that fluxes from shallow groundwater sources may be a significant source of moisture to the atmosphere.

In this context, recent studies have focused on the coupling of the groundwater component with the soil surface of LSM used for regional climate modeling [York et al., 2002; Gutowski et al., 2002; Maxwell and Miller, 2005; Fan et al., 2007; Niu et al., 2007; Anyah et al., 2008; Yuan et al., 2008; Yeh and Famiglietti, 2009; Jiang et al., 2009; Leung et al., 2011; Lo and Famiglietti, 2011; Miguez-Macho and Fan, 2012a, 2012b; Koirala et al., 2014]. They concluded that groundwater impacts the simulated water budget by providing much wetter soil in the LSMs when the water table is shallow. Low-frequency variations in the water table allow a more realistic water budget to be simulated by improving base flow in rivers and increasing evapotranspiration (ET) during dry periods. York et al. [2002] compared two runs of a regional coupled aquifer-land surface-atmosphere model with and without aquifer over a small catchment located in northeastern Kansas. They found that between $5 \%$ (wet year) and $20 \%$ (dry year) of ET is drawn from aquifer. By analyzing a 19 year observed hydrological data set in Illinois, Yeh and Famiglietti [2009] highlighted an upward capillary flux from groundwater that helps maintain the high summer ET rate. Thus, groundwater was found to be about $10 \%$ of total ET of the same period. More recently, Miguez-Macho and Fan [2012a] evaluated the role of groundwater in buffering the dry season soil moisture stress and ET by applying a fully coupled groundwater-surface water model at high resolution over the Amazon basin. Upward capillary flux from groundwater can reach the rooting zone and sustain dry season ET. They also concluded that, if the soil moisture content is already sufficient to satisfy the atmospheric demand of ET, an increase in the water content in the soil will not translate into an increase in ET.

The majority of these studies were carried out at high resolution for regional climate studies or hydrological applications. Only a few of them have addressed the impact of upward capillary fluxes at the low resolution generally used in global climate models [Niu et al., 2007; Yuan et al., 2008; Leung et al., 2011; Koirala et al., 2014]. Indeed, these large-scale simulations generally neglect the subgrid spatial variability of water table depth due to topographic heterogeneities and groundwater lateral flows. Moreover, these studies generally represent groundwater by extending the soil column depth rather than using a more physical approach based on a two-dimensional groundwater flow equation accounting for lateral flows, river-groundwater exchanges, and upward fluxes to the surface. Such assumptions are questionable for estimating groundwater capillary flux since this flux depends on the small-scale variability of water table head. In the first order, this small-scale variability of water table head depends directly on the spatial variability of topography [Tóth, 1963]. Yeh and Eltahir [2005a] used a statistical-dynamical approach to account for the subgrid water table dynamics for simulating grid-scale groundwater runoff with a lumped aquifer model. This parameterization was calibrated using an observational data set available over the studied region. However, such approach needs observations that are not available everywhere, especially when focusing at global scale. A more physically based approach is hence needed to account for the subgrid effect of topography at any spatial resolution.

In this study, a simple method is proposed for representing the upward capillary fluxes from shallow groundwater into the unsaturated soil of the large-scale hydrological models generally used at low resolution for global climate modeling. This new method is implemented into the ISBA-TRIP hydrological model [Alkama et al., 2010; Decharme et al., 2010]. The ISBA-TRIP hydrological model is composed of the Interaction SolBiosphère-Atmosphère (ISBA) land surface model and the Total Runoff Integrating Pathways (TRIP) riverrouting model. It is used in the Earth system model of Météo-France [Voldoire et al., 2013] through its implementation in the SURFace EXternalized modeling platform [Masson et al., 2013]. A two-dimensional diffusive groundwater scheme was recently developed in TRIP and tested in off-line mode with success over France and at the global scale [Vergnes and Decharme, 2012; Vergnes et al., 2012]. These studies demonstrate the feasibility of using this scheme at the resolution and time scales of climate models. Nevertheless, the simulated water table was not allowed to interact with the ISBA land surface model directly, and the possible upward capillary fluxes in the soil column were not taken into account.

The present study aims to describe the coupling between the groundwater scheme implemented in TRIP and the soil surface in ISBA by using a new original parameterization accounting for the subgrid spatial variability of topography. This parameterization is developed in order to be used at the coarse resolution of global 
climate models. Its impact is evaluated over France at high $\left(1 / 12^{\circ} \times 1 / 12^{\circ}\right)$ and low resolution $\left(0.5^{\circ} \times 0.5^{\circ}\right)$ over the 1979-2009 period. All simulations are forced by the same daily atmospheric forcing derived from the SAFRAN analyzing system [Durand et al., 1993]. An evaluation is made against two dense networks of river gauging stations and piezometers. The simulated terrestrial water storage (TWS) variations are also compared to the estimates from the Gravity Recovery and Climate Experiment (GRACE) satellite mission. The modeling framework is presented in section 2 and the experimental design in section 3. Section 4 presents the results, which are further discussed in section 5. Conclusions are drawn in section 6.

\section{The Modeling Framework}

\subsection{Overview of the TRIP RRM}

The basic concept and equations of the TRIP version including groundwater are described in Vergnes et al. [2012] and are only summarized here. The TRIP RRM is used to convert the total runoff simulated by ISBA into river discharges. TRIP is based on a prognostic mass balance equation for the stream water mass, which is solved at a $30 \mathrm{~min}$ time step within each grid cell of the hydrological network. TRIP takes a variable stream flow velocity into account to calculate the river discharges [Decharme et al., 2010]. The simple groundwater scheme implemented in TRIP is based on the two-dimensional groundwater flow equation for the water table head $H(\mathrm{~m})$. This equation has been rewritten in spherical coordinates in order to take into account the spherical form of the Earth and to be solved on the regular longitude/latitude grid used in global climate model. Only the uppermost unconfined aquifer layer is solved

$$
\omega \frac{\partial H}{\partial t}=\frac{1}{r^{2} \cos (\varphi)}\left[\frac{\partial}{\partial \theta}\left(\frac{T_{\theta}}{\cos (\varphi)} \frac{\partial H}{\partial \theta}\right)+\frac{\partial}{\partial \varphi}\left(T_{\varphi} \cos (\varphi) \frac{\partial H}{\partial \varphi}\right)\right]+q_{\mathrm{sb}}-q_{\text {riv }}
$$

where $\omega\left(\mathrm{m}^{3} \mathrm{~m}^{-3}\right)$ is the specific yield corresponding here to the effective porosity, $\theta$ and $\varphi$ are the longitude and latitude coordinates, respectively, $r(\mathrm{~m})$ is the mean radius of the Earth, and $T_{\theta}$ and $T_{\varphi}\left(\mathrm{m}^{2} \mathrm{~s}^{-1}\right)$ are the transmissivities of the aquifer along the longitude and the latitude axes, respectively. The parameter $q_{\mathrm{sb}}\left(\mathrm{m} \mathrm{s}^{-1}\right)$ is the recharge provided by ISBA per unit area of aquifer and $q_{\text {riv }}\left(\mathrm{m} \mathrm{s}^{-1}\right)$ the groundwater-river flux per unit area. This equation is then discretized and solved in $\mathrm{m}^{3} \mathrm{~s}^{-1}$ in TRIP at each time step for one layer corresponding to an unconfined aquifer. The coupling with ISBA is performed every $3 \mathrm{~h}$. The groundwaterriver exchanges are computed as follows:

$$
Q_{\text {riv }}=\mid \begin{array}{ll}
\operatorname{RC}\left(H-H_{\text {riv }}\right) & \text { where } H>Z_{\text {bed }} \\
\operatorname{RC}\left(Z_{\text {bed }}-H_{\text {riv }}\right) & \text { where } H<Z_{\text {bed }}
\end{array}
$$

$Q_{\text {riv }}\left(\mathrm{m}^{3} \mathrm{~s}^{-1}\right)$ represents the groundwater-river exchanges, $H_{\text {riv }}(\mathrm{m})$ the river stage elevation, $Z_{\text {bed }}(\mathrm{m})$ the river bed elevation, and $\mathrm{RC}\left(\mathrm{m}^{2} \mathrm{~s}^{-1}\right)$ the river conductance. These parameters are computed as follows:

$$
\begin{aligned}
\mathrm{RC} & =\frac{L W}{\tau} \\
Z_{\text {bed }} & =Z-h_{c} \\
H_{\text {riv }} & =Z_{\text {bed }}+\min \left(h_{c}, h_{s}\right)
\end{aligned}
$$

$L(\mathrm{~m})$ and $W(\mathrm{~m})$ are the length and the width of the river inside the cell, respectively, while $\tau(\mathrm{s})$ is the coefficient of the transfer time of water through the river bed sediment. $Z(\mathrm{~m})$ corresponds to the river elevation in the grid cell, $h_{c}(\mathrm{~m})$ to the river bankfull height, and $h_{s}(\mathrm{~m})$ to the river water height. More details on the concept and numerical method of the groundwater scheme can be found in Vergnes et al. [2012].

\subsection{ISBA Land Surface Scheme}

ISBA contains the basic physics of the land surface and requires only a limited number of parameters, which depend on the type of soil and vegetation. In the present study, the multilayer soil scheme is used to solve both the one-dimensional Fourier law and the mixed form of the Richards equation explicitly in order to calculate the time evolution of the soil energy and water budgets [Boone et al., 2000; Decharme et al., 2011]. This approach allows explicit representation of the surface/groundwater capillarity exchanges [Maxwell and Miller, 2005; Miguez-Macho et al., 2007; Anyah et al., 2008] as well as the vertical distribution of the root profile in the soil [Braud et al., 2005], which are of particular interest for our study. A detailed description of the ISBA multilayer soil scheme can be found in Decharme et al. [2011, 2013]. 
(a) Free-drainage

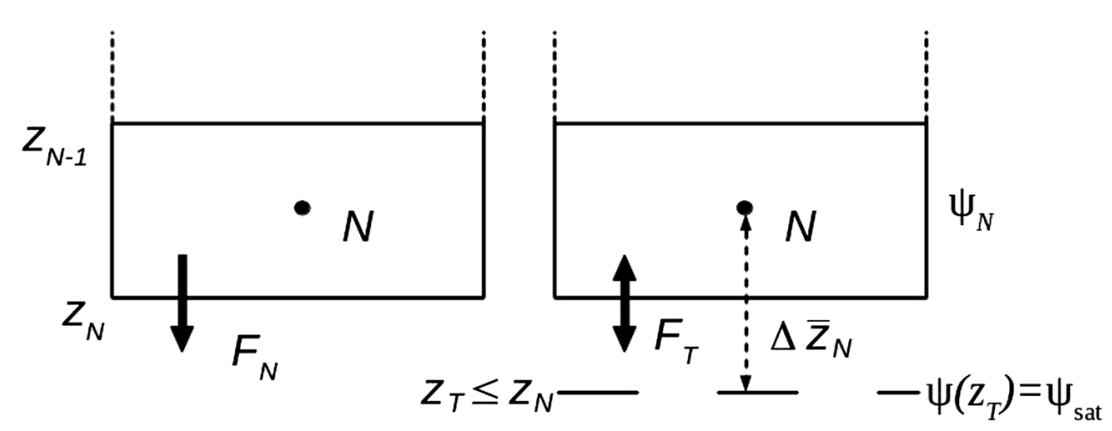

(b) Fully-coupled (c) 30" topography

$\mathrm{m}$

\section{(d) Normalized accumulated distribution of topography}
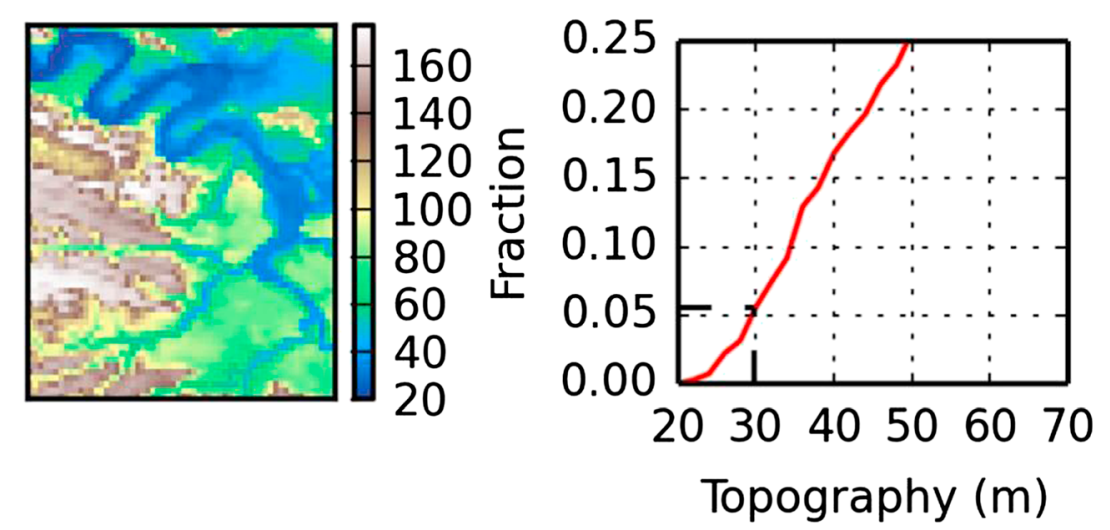

Figure 1. (a) Free drainage gravity and (b) fully coupled bottom conditions, (c) One kilometer topography inside a $0.5^{\circ}$ grid cell, and (d) fractions of the grid affected by upward capillary flux for a given elevation (hence water table head) estimated as the normalized distribution of the topography in the cell. $Z_{N-1}\left(Z_{N}\right)(\mathrm{m})$ is the depth of the $N-1(N)$ layer, $\Psi_{N}(\mathrm{~m})$ the matric potential of the layer $N, \Psi_{\text {sat }}(\mathrm{m})$ the saturated matric potential, and $\Delta \bar{z}_{N}(\mathrm{~m})$ the distance between the water table and the node $N$.

The heat transfer within the soil is computed using 14 layers up to $12 \mathrm{~m}$ depth. Conversely, the soil depth for moisture varies from $0.2 \mathrm{~m}$ to $2 \mathrm{~m}$ according to the rooting depth of each ISBA land cover [Decharme et al., 2013]. For example, if the soil depth for moisture is equal to $1 \mathrm{~m}$, the Richard's equation is solved within the first eight layers, whereas soil temperatures are computed over all layers. The simulation of freezing and thawing processes is thus facilitated by the colocalization between hydrologic and thermal nodes. At the bottom of the soil moisture a free drain condition (Figure 1a) is applied in ISBA that acts as the recharge for the groundwater scheme in TRIP:

$$
F_{N}=k_{N}
$$

where $k_{N}\left(\mathrm{~m} \mathrm{~s}^{-1}\right)$ is the hydraulic conductivity of the last soil layer $N$. Note that this version of the ISBA multilayer soil scheme has recently been successfully evaluated over France using a dense network of in situ observations, such as river discharges and soil temperature profile [Decharme et al., 2013].

\subsection{Upward Capillary Fluxes}

The free drain bottom condition can be modified in order to account for the presence of water table under the soil moisture column. The river elevation $Z$ is taken as the reference when calculating the water table depth $Z_{T}(\mathrm{~m})$ in the grid cell:

$$
Z_{T}=Z-H
$$


The top of the water table located beneath the soil column is assumed to be saturated. Therefore, the lower boundary condition $F_{T}$ for soil moisture can be expressed using the Richard's equation (Figure $1 \mathrm{~b}$ ):

$$
F_{T}=k_{N}\left[\frac{\left(\psi_{N}-\psi_{\text {sat }}\right)}{\Delta \bar{z}_{N}}+1\right]
$$

where $\Psi_{N}(\mathrm{~m})$ is the matric potential of the last soil moisture layer $N$ and $\Psi_{\text {sat }}$ the saturated matric potential, assuming that $\Psi\left(Z_{T}\right)=\Psi_{\text {sat. }}$. The distance $\Delta \bar{z}_{N}(\mathrm{~m})$ between the water table depth and the last node of the soil moisture layers is

$$
\Delta \bar{z}_{N}=\max \left(z_{T}, z_{N}\right)-\frac{\left(z_{N}+z_{N-1}\right)}{2}
$$

In the limit, as $Z_{T}$ becomes large, equation (6) collapses into the simple free drain bottom condition given by equation (4).

Considering $F_{T}$ as the soil bottom condition of ISBA supposes that the entire grid cell is concerned by upward capillary fluxes. Such hypothesis is highly questionable. Only a fraction of the grid cell corresponding to the flat valleys and alluvial plains should be considered. This fraction must reflect the subgrid spatial variability of topography inside each grid cell, which can be significant considering the coarse resolution of the climate models (Figure 1c). For example, a grid cell with steeper topography would allow upward capillary fluxes on a small fraction of the cell, unlike the cells with flatter terrain. Calling this fraction $f_{\mathrm{wtd}}$, the final flux calculated at the bottom of the soil column is

$$
F=f_{\text {wtd }} F_{T}+\left(1-f_{\text {wtd }}\right) F_{N}
$$

This final flux $F$ encompasses the upward capillary flux and downward flux (gravity drainage) at the bottom of the soil.

As this coupling fraction $f_{\text {wtd }}$ must reflect the subgrid spatial variability of the topography inside the grid cell, it cannot be determined solely from the simulated grid-mean water table head $H$. A subgrid approach is proposed here to compute $f_{\text {wtd: }}$ for each grid cell, the accumulated normalized distribution of the 30 arc second resolution elevation inside a $1 / 12^{\circ}\left(0.5^{\circ}\right.$ respectively) cell is computed. Figure $1 c$ shows an example of the 30 arc second resolution topography inside a $0.5^{\circ}$ grid cell and Figure $1 \mathrm{~d}$ the corresponding normalized accumulated distribution of topography. The simulated water table head is then directly compared to this high-resolution topography, and a fraction $f_{\text {wtd }}$ is deduced. This fraction could logically be equal to zero if the simulated water head deepens under the minimum topographic value inside the cell. Nevertheless, $f_{\mathrm{wtd}}$ is bounded to a small value corresponding to the river elevation $Z$ in the cell. It corresponds to the dashed line in the example of Figure $1 \mathrm{~d}$. Thus, even if the water table falls under the river elevation $Z$, upward capillary fluxes can occur over a minimum fraction of the cell.

\section{Experimental Design}

\subsection{Experiments}

ISBA-TRIP was integrated at the $1 / 12^{\circ}$ high resolution, in order to take advantage of the numerous observations available to assess the model, and at the $0.5^{\circ}$ low resolution compatible with the global application. For each resolution, the coupled simulation was compared to the control experiment. The simulations were named as follows:

1. NOCPL: control simulation at high resolution without upward capillary fluxes

2. NOCPL05: same as NOCPL but at low resolution

3. CPL: coupled simulation at high resolution

4. CPL05: same as CPL but at low resolution

Two supplementary experiments, called CPLNOF and CPLNOF05, were also performed without using the coupling fraction; that is, by considering groundwater capillary fluxes occurring over the entire grid cell.

ISBA-TRIP is forced by the SAFRAN atmospheric forcing at an hourly time step over a 30 year period, starting from 1 August 1979 and ending on 31 July 2009. An initial 30 year spin-up simulation was performed by repeating the 1979-1989 period 3 times in order to allow the ISBA diffusive soil scheme to reach equilibrium. The model was then evaluated over the 1989-2009 period. 
The SAFRAN analysis system provides eight atmospheric parameters computed over the French domain: the $10 \mathrm{~m}$ wind speed, $2 \mathrm{~m}$ relative humidity, $2 \mathrm{~m}$ air temperature, cloudiness, incoming solar and atmospheric radiations, snowfall, and rainfall. The total daily precipitation is analyzed using observational data from over 3500 gauges, together with a vertical gradient of precipitation (with altitude) derived from climatology. These precipitation data are then interpolated at an hourly time step following the daily cycle of the observed air humidity and temperature and the solar radiation. Further details of the SAFRAN analysis system over France can be found in Quintana-Seguí et al. [2008].

\subsection{Parameters}

The experimental framework of this study is described in detail in Vergnes et al. [2012]. Only the aspects relevant to understanding the present study are described. The river elevation $Z$ is derived from the Global 30 Arc-Second Elevation Data Set (GTOPO30) digital elevation model. Each grid cell topography at $1 / 12^{\circ}$ $\left(0.5^{\circ}\right.$ respectively) resolution is computed as the average value of the first decile of the actual 30 arc second resolution topographic values within the grid cell, ranked in ascending order. This elevation reflects the altitude of the river in the grid cell and is included in the calculation of the riverbed height $Z_{\text {bed. }}$ Previous results over France show that using such topography gives more realistic simulated river discharges [Vergnes et al., 2012].

In order to simulate realistic upward capillary fluxes, water table depth must be simulated realistically in the model. In this study, water table depth is computed with respect to the river elevation $Z$. Since the river can potentially exchange water with the underlying aquifer in all the cells, water table depth strongly depends on the river geometry. Thus, new geomorphological relationships were derived from observations to compute the river widths $W$ and the river bankfull heights $h_{c}$ from the annual mean river discharges $Q_{m}$. (see Appendix A). These formulations are written as follows:

$$
\begin{aligned}
W & =5.41 Q_{m}^{0.59} \\
h_{c} & =2.31 Q_{m}^{0.17} \\
h_{c} & =1.4 W^{0.28}
\end{aligned}
$$

$W$ is estimated for each grid cell using the mean-simulated annual discharges from the total runoff simulated by ISBA at each resolution, and $h_{c}$ is calculated through equation (9c). These relationships are meant to be more realistic than those used in Vergnes et al. [2012], since they are based on data collected on the whole aquifer domain.

The ISBA land surface configuration and parameters used in this version are the same as those in Decharme et al. [2013]. The land surface parameters are specified according to the $1 \mathrm{~km}$ resolution ECOCLIMAP-II database developed at Météo-France [Faroux et al., 2013]. Two hundred seventy-three land cover units are defined at this resolution using climate information, the Corine Land Cover map for the year 2000 at a $100 \mathrm{~m}$ resolution over Europe, and the Global Land Cover 2000 database [Bartholomé and Belward, 2005]. The rooting depth defined in ISBA is specified for each land cover according to Canadell et al. [1996]. This depth is used as the depth for soil moisture and varies from 0 to $2 \mathrm{~m}$ [Decharme et al., 2013].

\subsection{Evaluation Data Set}

In situ river daily discharge measurements were selected at 158 gauging stations to evaluate the impact of the upward capillary fluxes over the simulated discharges at high resolution. Only time series located over an aquifer and with a minimum period of 10 years were used. Moreover, when several gauging stations were located in one cell, the largest observed drainage area was retained. Forty-six gauging stations were selected at low resolution using the same approach as that at high resolution. Water table heads are also well monitored over France, and numerous data are available in the ADES database (http://www.ades.eaufrance. $\mathrm{fr} /$ ). About 400 water table observations were selected over the 1989-2009 period, corresponding to an unconfined aquifer and not strongly affected by pumping.

The simulated Terrestrial Water Storage (TWS) variations were compared to the GRACE estimates. GRACE provides monthly TWS variations in terms of anomalies ( $\triangle T$ TWS) based on highly accurate maps of the Earth's gravity fields at monthly intervals and at spatial length scales of about 300-400 km [Swenson et al., 2003; Wahr et al., 2004]. The instrumentation and on-board instrument processing units are described in detail by 
(a) NOCPL Efficiency

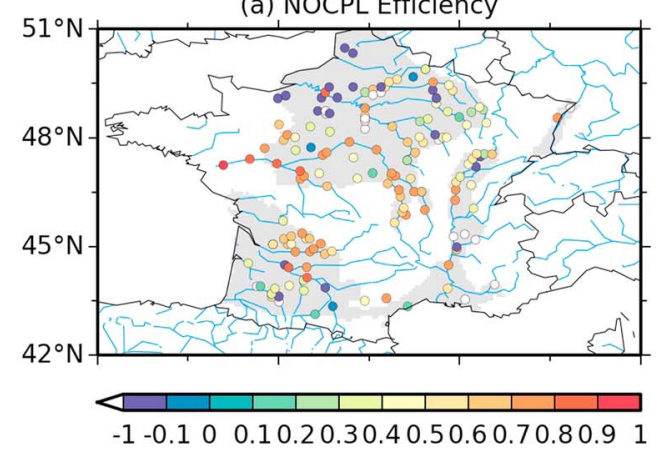

(c) NOCPL Ratio

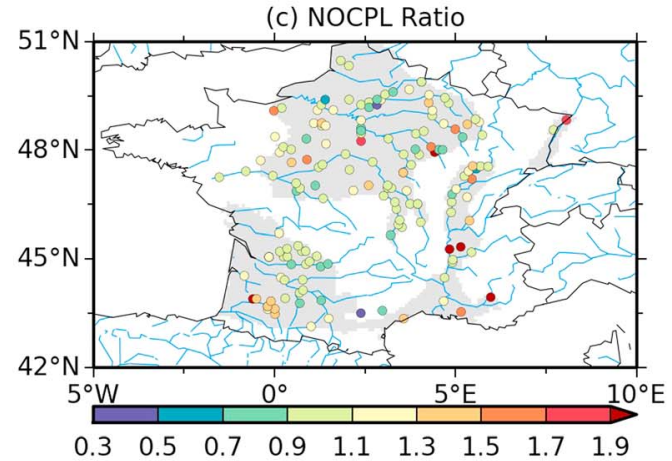

(e) Accumulated Distribution of Efficiency

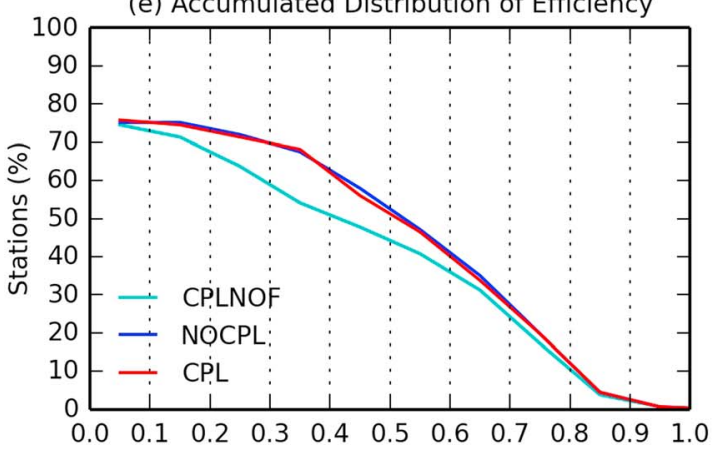

(b) CPL-NOCPL Efficiency Difference

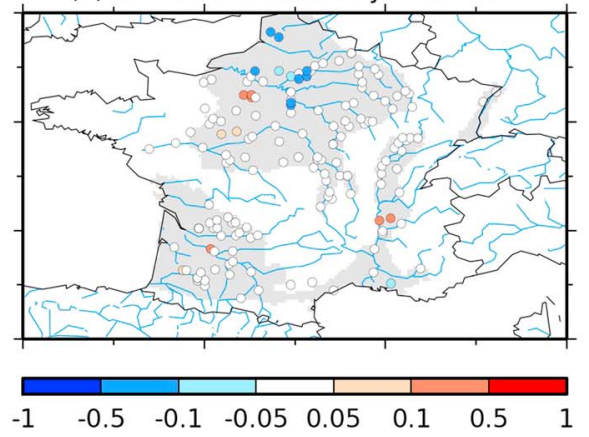

(d) CPL - NOCPL Annual Ratio Difference

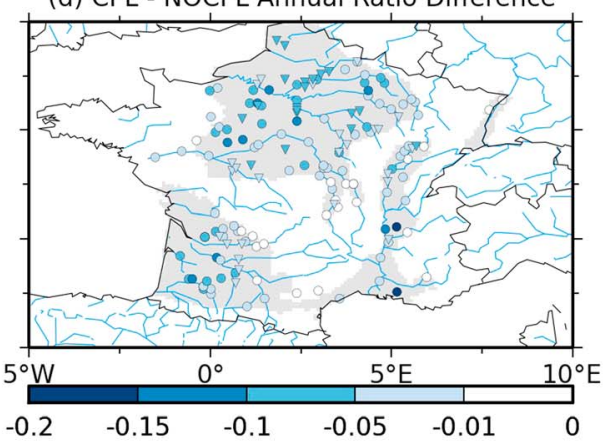

(f) Annual Ratio Distribution

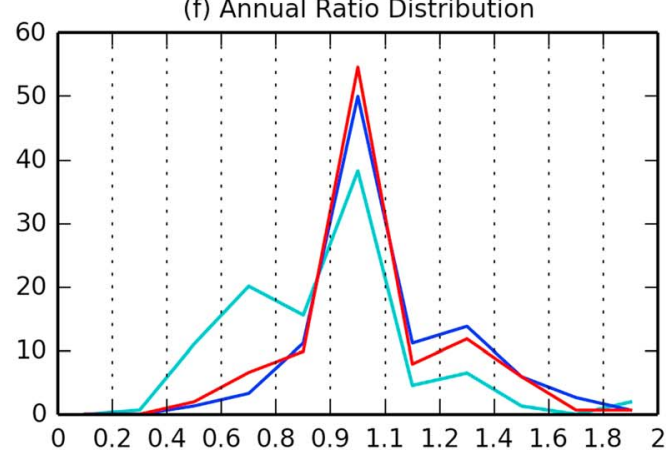

Figure 2. Evaluation of the simulated daily discharges with (CPL) and without (NOCPL) upward capillary fluxes. (a) The spatial distribution of the NOCPL efficiencies, (c) the NOCPL annual ratios are given at each 157 gauging stations, as well as $(b, d)$ the differences with the CPL scores. Circle on Figure $2 \mathrm{~d}$ means an improvement and triangles a deterioration. (e) The cumulative distributions of the daily efficiency and (f) the ratio distributions also shown for NOCPL, CPL, and CPLNOF.

Berti et al. [2003]. GRACE data can be used in a hydrological application to estimate $\triangle$ TWS from basin [Crowley et al., 2006; Seo et al., 2006] to continental scale [Tapley et al., 2004; Schmidt et al., 2006]. GRACE has also been used to evaluate groundwater schemes [Niu et al., 2007; Decharme et al., 2010; Lo et al., 2010; Vergnes and Decharme, 2012]. The impact of upward capillary flux from groundwater to the overlying unsaturated zone over the simulated $\Delta$ TWS is evaluated against 85 months (from July 2003 to July 2009) of the Release 04 data produced by the Center for Space Research (CSR at the University of Texas at Austin) averaged over the entire aquifer area defined over France at low and fine resolutions [Swenson and Wahr, 2006].

\section{Results}

\subsection{River Discharges}

The simulated river discharges with and without upward capillary fluxes were first compared to gauge measurements. This evaluation was made with the help of usual hydrological skill scores: the annual 

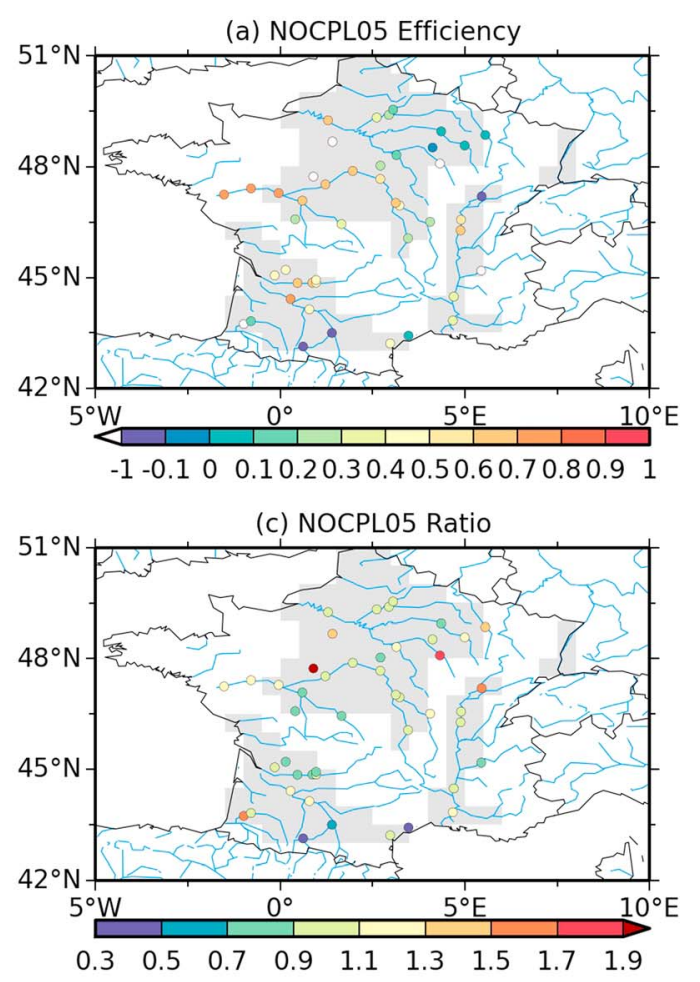

(e) Accumulated Distribution of Efficiency

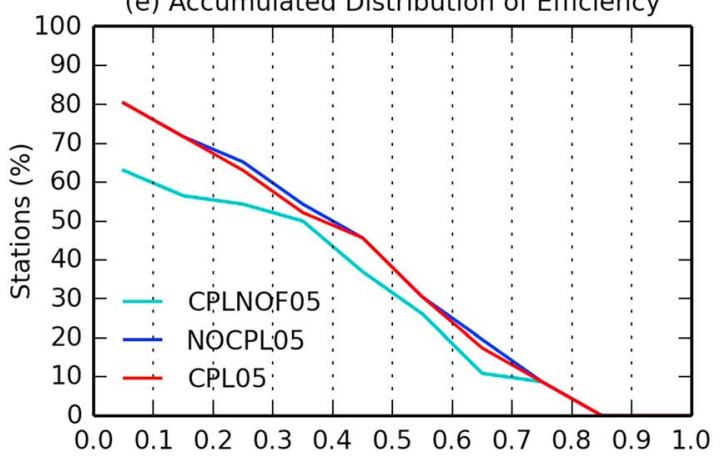

(b) CPL05-NOCPL05 Efficiency Difference

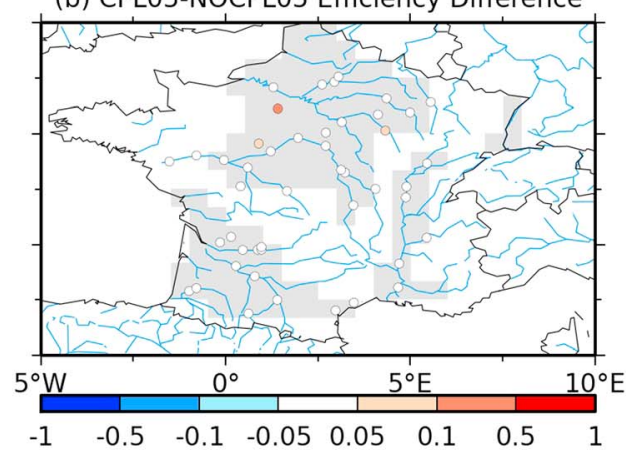

(d) CPL05 - NOCPL05 Annual Ratio Difference

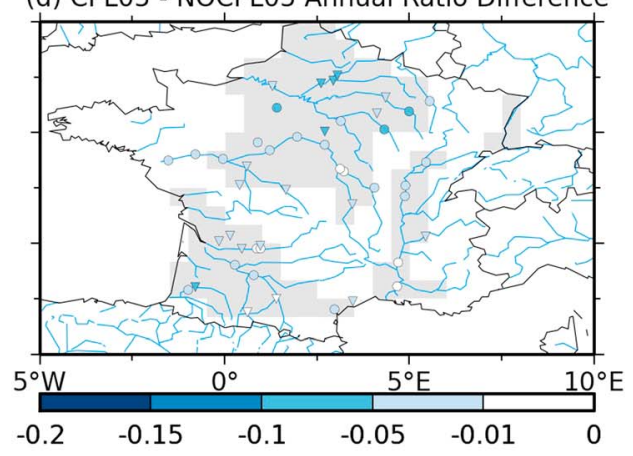

(f) Annual Ratio Distribution

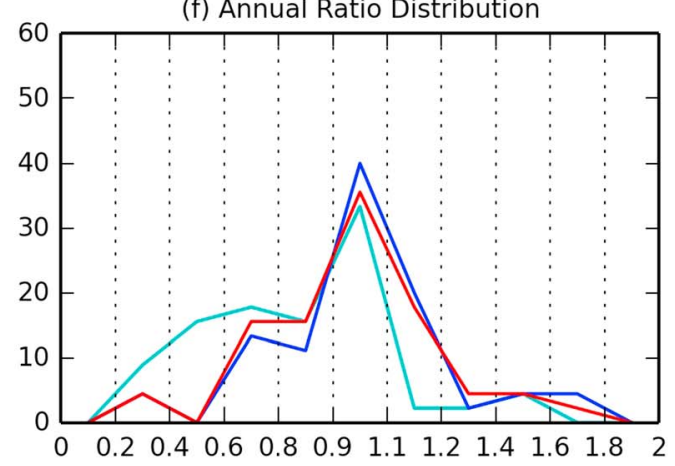

Figure 3. Same as Figure 2 but for NOCPL05, CPL05, and CPLNOF05.

discharge ratio criterion, the RMSE, and the efficiency (Eff) criterion [Nash and Sutcliffe, 1970], which measures the ability of the model to capture the daily discharge dynamics. This last skill score is defined as follows:

$$
\text { Eff }=1.0-\frac{\sum\left(Q_{\text {sim }}(t)-Q_{\text {obs }}(t)\right)^{2}}{\sum\left(Q_{\text {obs }}(t)-\overline{Q_{\text {obs }}}\right)^{2}}
$$

where $Q_{\text {sim }}(t)$ represents the simulated river discharge, $Q_{\text {sim }}(t)$ the observed river discharge and $\overline{Q_{\text {obs }}}$ the observed temporal mean. Eff can be negative if the simulated discharge is very poor and is above 0.5 for a reasonable simulation. The annual discharge ratio criterion is defined as follows:

$$
\text { Ratio }=\frac{\overline{Q_{\text {sim }}}}{\overline{Q_{\text {obs }}}}
$$

Figure 2a shows the spatial distribution of the daily discharge efficiencies in the free drain experiment at fine resolution (NOCPL), while Figure $2 b$ compares these scores with the fully coupled simulation. The NOCPL efficiency scores are negative in the northern part of the Paris basin and over a few stations located in the Garonne and Rhone basins. The scores are higher in other parts of the simulated French aquifer domains. The NOCPL annual ratios shown in Figure 2c point out an overestimation of the simulated river discharges compared to observations over $32 \%$ of the gauging stations, while $53 \%$ are more balanced. Considering water capillary 

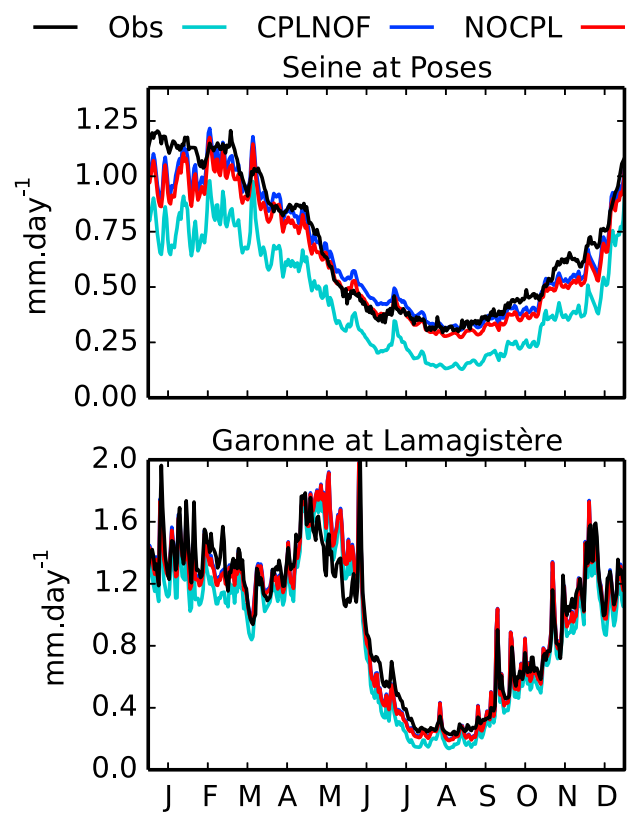
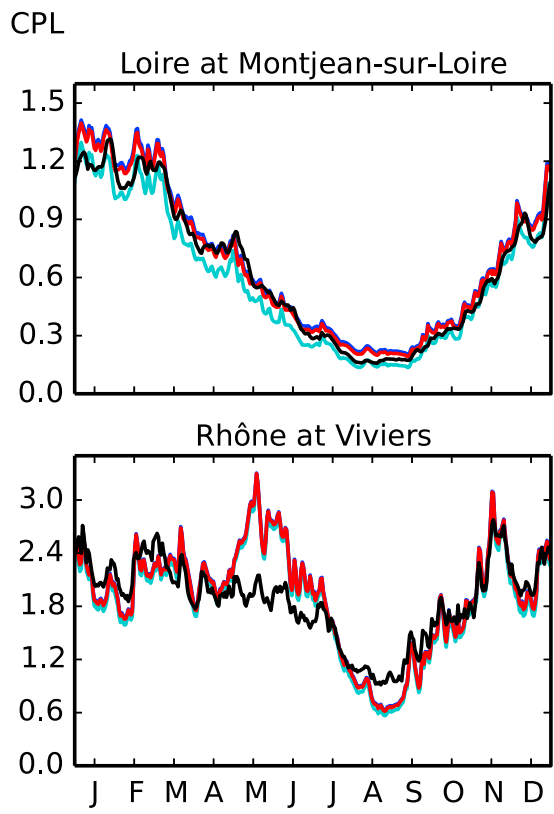

Figure 4. Daily mean annual cycles of the simulated and observed river discharges at the outlets of the four main rivers for NOCPL, CPL, and CPLNOF.

rises slightly affects the efficiency scores. Only $6 \%$ of them are improved, while $7 \%$ are deteriorated, mostly over the northern part of the Seine basin (Figure $2 b$ ). The comparison of annual ratios in Figure $2 \mathrm{~d}$ demonstrates that upward capillary fluxes lead to a decrease in river discharges, in particular, at the downstream of river basins. Gauging stations represented by circles show an improved annual ratio due to upward capillary fluxes, while the inverse is true for those represented by triangles. The simulated annual discharges are therefore more balanced over the entire domain, except in few areas, especially in the northern Paris basin. So the number of stations for which the annual ratio is overestimated decreases to $29 \%$, while $56 \%$ are more balanced.

The comparison of the accumulated distribution of efficiency scores in Figure $2 e$, in which the CPL curve is superimposed onto NOCPL, confirms the limited impact of the upward capillary fluxes on efficiency. As already stated, the impact is clearer when the annual ratio is considered: the CPL ratio distribution shown in Figure $2 \mathrm{f}$ is superior to NOCPL with a higher peak around the 1 value. Finally, the CPLNOF sensitivity experiment curves are also shown in Figures $2 \mathrm{e}$ and $2 \mathrm{f}$. The accumulated distribution of efficiency is inferior to $C P L$, while the mean annual ratios are now underestimated. These results clearly demonstrate the benefit of taking into account a fraction based on topography to limit upward capillary fluxes.

Similar results are found for the discharge analysis at low resolution (NOCPL05, CPL05, and CPLNOF05, Figure 3). Nevertheless, the impact of upward capillary fluxes on the simulated river discharges seems to be lower at this resolution. Of the 46 selected gauging stations shown in Figure 3b, 93\% do not present major changes in terms of efficiency scores. The principal difference compared to the high-resolution results can be found in the annual ratio distributions, where CPL05 slightly underestimates the simulated annual discharges compared to NOCPL05. This contradiction with the results shown in Figure $2 \mathrm{f}$ can be explained by the low number of gauging stations at $0.5^{\circ}$. Finally, CPLNOF05 underestimates the mean annual ratios and deteriorates the efficiencies as in CPLNOF.

Figure 4 compares observed and simulated daily river discharges at the outlets of the four main watersheds of France in terms of daily mean annual cycle and only at high resolution. As expected, the NOCPL and CPL curves are quasi-similar. At the outlet of the Seine basin, river flow is underestimated during winter, while base flow is better reproduced with CPL. The CPLNOF river discharges are drastically underestimated compared to observations. Table 1 gives the daily scores computed over the 1989-2009 period at the outlets of the four main watersheds of France for both high- and low-resolution simulations. The scores with and without upward capillary fluxes are very similar, whatever the resolution. In consequence, the upward capillary fluxes do not affect the interannual variability of the simulated river discharges. 
Table 1. Statistical Scores Simulated at the Outlets of the Four Main Rivers of France

\begin{tabular}{lccccc} 
Name of River & & Efficiency & Correlation & Ratio & RMSE \\
\hline Seine & NOCPL & 0.81 & 0.91 & 0.96 & 0.19 \\
& CPL & 0.8 & 0.9 & 0.91 & 0.2 \\
& CPLNOF & 0.57 & 0.88 & 0.67 & 0.29 \\
& NOCPL05 & 0.6 & 0.79 & 0.98 & 0.28 \\
Loire & CPL05 & 0.59 & 0.79 & 0.94 & 0.29 \\
& CPLNOF05 & 0.36 & 0.76 & 0.69 & 0.36 \\
& NOCPL & 0.88 & 0.94 & 1.08 & 0.2 \\
& CPL & 0.89 & 0.94 & 1.06 & 0.19 \\
& CPLNOF & 0.88 & 0.94 & 0.92 & 0.2 \\
Naronne & 0.72 & 0.88 & 1.16 & 0.31 \\
& NOCPL5 & 0.72 & 0.88 & 1.14 & 0.3 \\
& CPL05 & 0.72 & 0.87 & 1.0 & 0.3 \\
& CPLNOF05 & 0.84 & 0.92 & 0.0 & 0.39 \\
& NOCPL & 0.84 & 0.92 & 0.99 & 0.39 \\
& CPL & 0.82 & 0.91 & 1.15 & 0.41 \\
Rhône & CPLNOF & 0.48 & 0.82 & 1.14 & 0.69 \\
& NOCPL05 & 0.48 & 0.81 & 0.69 \\
& CPL05 & 0.47 & 0.81 & 1.06 & 0.7 \\
& CPLNOF05 & 0.9 & 1.03 & 0.45 \\
& NOCPL & 0.73 & 0.9 & 0.99 & 0.45 \\
& CPL & 0.73 & 0.9 & 1.03 & 0.45 \\
& CPLNOF & 0.74 & 0.82 & 1.03 & 0.69 \\
& NOCPL05 & 0.38 & 0.81 & 0.71 \\
\hline
\end{tabular}

\subsection{Water Table Heads and Terrestrial Water Storage}

Simulated and observed water table heads are compared in terms of biases computed as follows:

$$
\text { Bias }=\frac{1}{n} \sum_{i=1}^{n}\left(H_{\mathrm{sim}, i}-H_{\mathrm{obs}, i}\right)
$$

where $n$ is the number of observed values, $H_{\text {sim, } i}$ the simulated water table heads, and $H_{\text {obs }, i}$ the observed water table heads, with $i$ denoting the time step.

Figure 5 a shows the spatial distribution of the 428 selected water table head biases for NOCPL and the associated bias histogram for NOCPL, CPL, and CPLNOF. The water table heads are largely underestimated in some parts of the Paris basin and estimated quite well over the Aquitaine basin and the Rhine alluvial plain. The bias histogram in Figure $5 b$ reveals a shift toward negative biases for NOCPL. The simulated water table depths are generally lower than in observations. The CPL experiment exhibits the same behavior and does not significantly impact the results. However, CPLNOF clearly deteriorates these biases, as it simulates a lower water table depth compared to the other experiments.

In order to better understand these results, a distinction is made between observation wells located near and far from rivers. The comparison of the observation wells with the SYRAH hydrographic network [Chandesris et al., 2009] allows us to distinguish between 182 observations located within $1 \mathrm{~km}$ from a river (triangles and plain colors in Figures $5 \mathrm{a}$ and $5 \mathrm{~b}$ respectively) and 246 farther from rivers (circles and transparent colors). In the first case, the distributions are more balanced over biases varying between -2 and $2 \mathrm{~m}$, which is not the case when considering all the piezometers. Moreover, the observation wells located far from rivers represent about $61 \%$ of the total negative biases whatever the considered simulation. It shows that the simulated water table heads are better reproduced along the river, which was expected given the configuration of the model. The gray bars in Figure $5 \mathrm{~b}$ represent differences between the local piezometer elevation and the river elevation $Z$ used as the reference for computing water table depths. This distribution is shifted largely toward negative values. It shows that negative biases found for the simulations are essentially due to the difference between the river mean elevation used to simulate the water table depths and the local topography where the piezometer is located.

In order to evaluate the interannual variability of water table heads, Figure 6 shows the comparison between the observed and simulated daily water tables over the 1989-2009 period. Four piezometers are selected so 

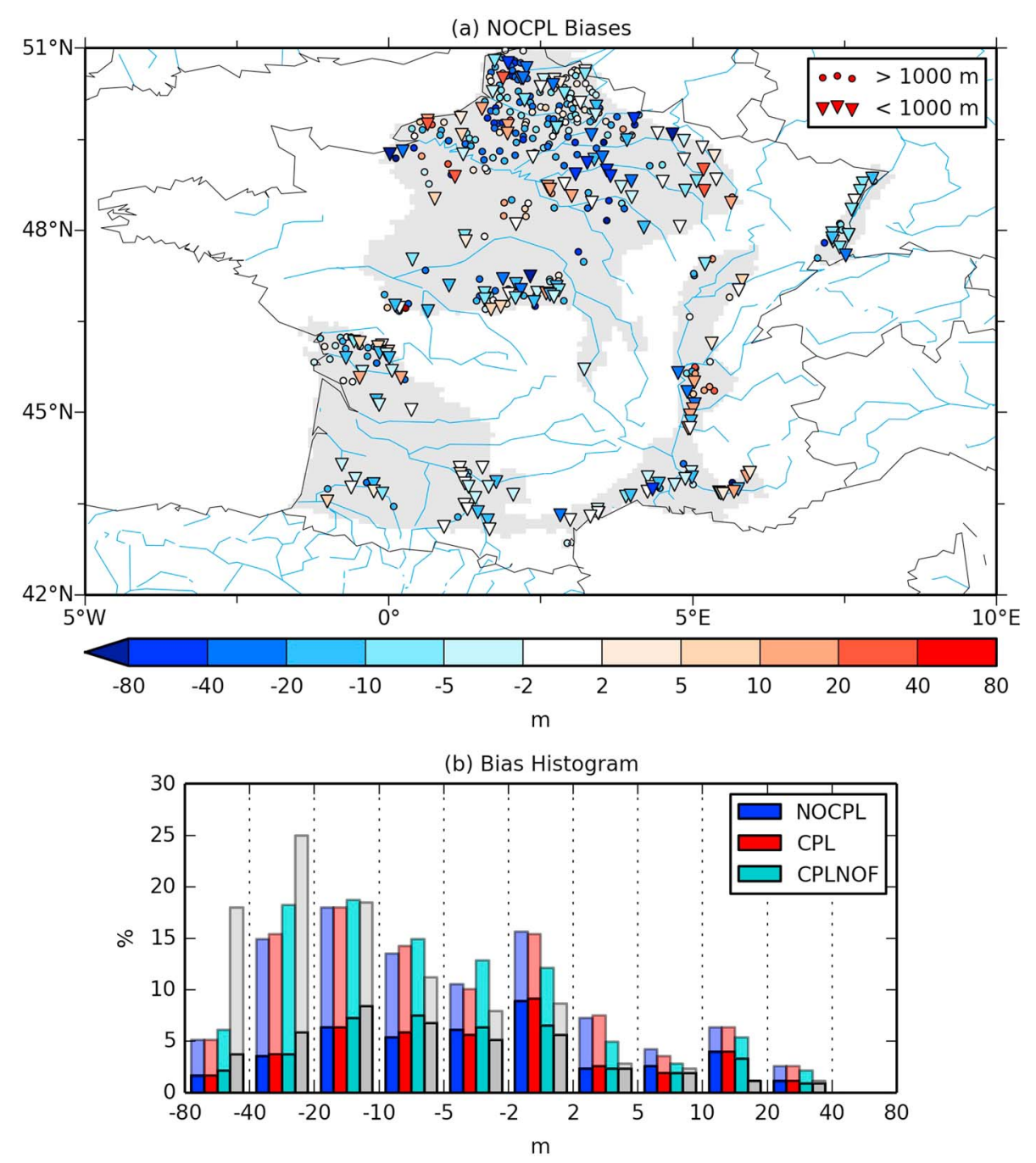

Figure 5. Comparison between observed and simulated water table heads at the 428 observation wells over the 1989-2009 period. (a) NOCPL bias and (b) bias histograms for NOCPL, CPL, and CPLNOF. The observations located at most at $1 \mathrm{~km}$ of a river correspond to triangles (Figure $5 \mathrm{a}$ ) and plain colors (Figure $5 \mathrm{~b}$ ), respectively, the remaining observations to circles and transparent colors. Gray colors in Figure $5 \mathrm{~b}$ denote the difference between the observation altitude and the river elevation $Z$.

as to be the most representative of the overall results. The first two piezometers are located near rivers (Figures $6 \mathrm{a}$ and $6 \mathrm{~b}$ ) and the other two are located far from rivers (Figures $6 \mathrm{c}$ and $6 \mathrm{~d}$ ). The NOCPL, CPL, and CPLNOF simulations are shown. Correlation and RMSE scores are provided for each piezometer. The only significant effect of the upward capillary fluxes is to lower the water table head. RMSE scores are either improved (Figures $6 \mathrm{~b}$ and $6 \mathrm{c}$ ) or deteriorated (Figures $6 \mathrm{a}$ and $6 \mathrm{~d}$ ), while correlation scores are almost identical. Nevertheless, these differences are rather weak. The upward capillary fluxes do not deteriorate the comparison with observed water table heads but do not improve it either. Conversely, the CPLNOF simulation generally deteriorates this comparison.

Figure 7 shows the mean water table depths computed for NOCPL, CPL, NOCPL05, and CPL05. The spatial patterns are quasi-similar between free drain and fully coupled simulations. Water table depth is always between 0 and $6 \mathrm{~m}$ at low resolution, while it can fall under $6 \mathrm{~m}$ at high resolution. However, water table depths tend to be deeper over the main riverbed at low resolution than at high resolution. The temporal average of the fraction $f_{\text {wtd }}$ is shown for CPL and CPL05 in Figures 7e and 7f, respectively. This fraction is generally lower than 0.1 , meaning that less than $10 \%$ of the grid cell is concerned by upward capillary fluxes. However, this fraction can be superior to $10 \%$ at high resolution, mainly along rivers and over the coast, 


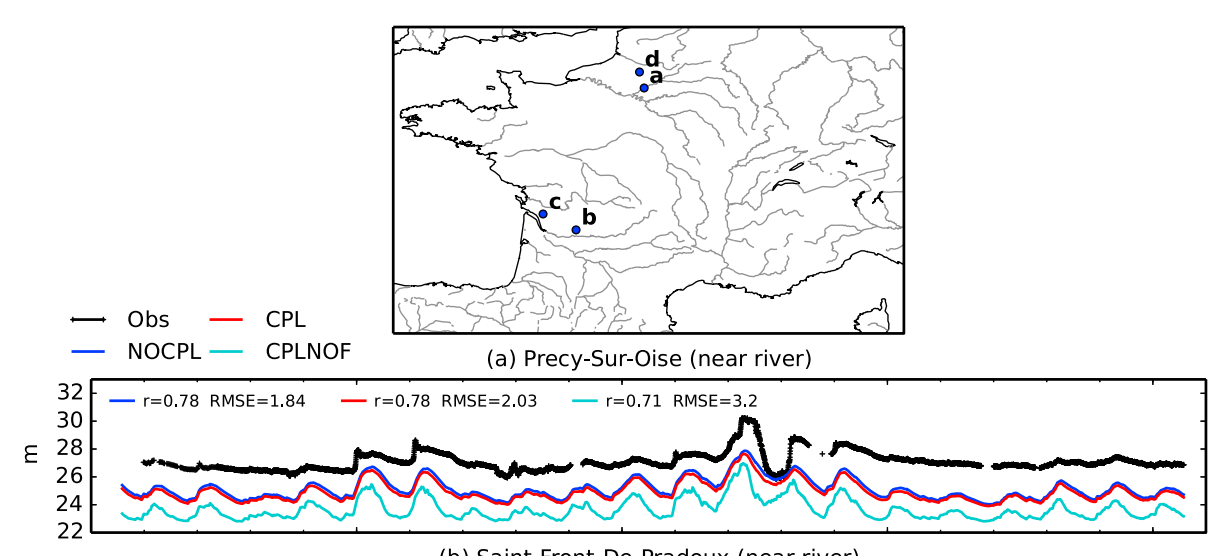

(b) Saint-Front-De-Pradoux (near river)

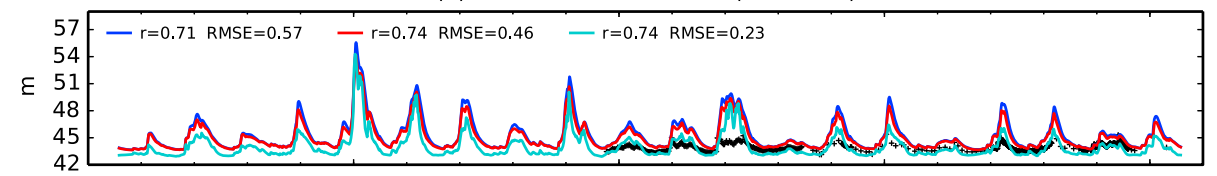

(c) Bois (far from river)

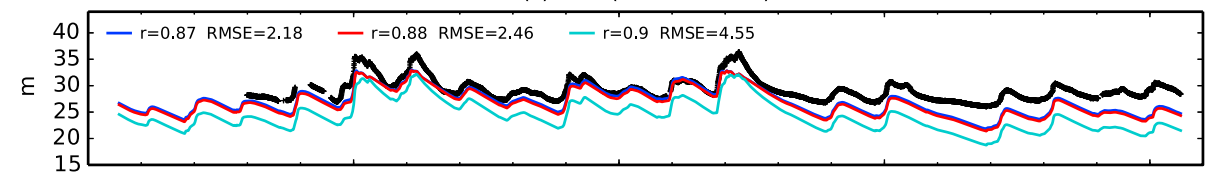

(d) Bonneuil-Les-Eaux (far from river)

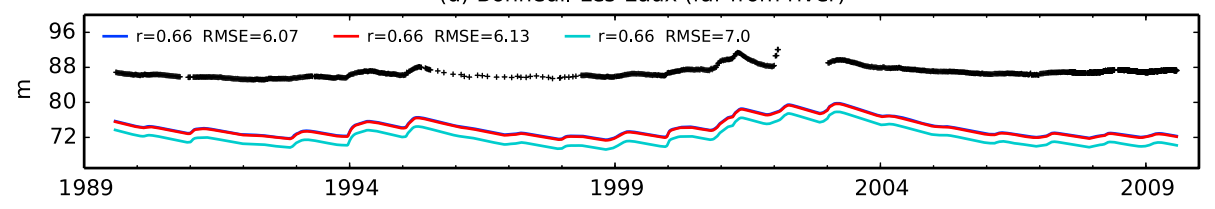

Figure 6. Time series of observed and simulated daily water table heads at (a)-(d) four selected piezometers for NOCPL, $\mathrm{CPL}$, and CPLNOF. RMSE and correlation scores are given for each piezometer. The location of each piezometer is shown in the top panel.

which is coherent with the fact that upward capillary fluxes are expected to occur for shallow groundwater, generally located over alluvial plains. This behavior is unfortunately less present at low resolution.

Finally, Figure 8 a shows the monthly mean annual cycles of the simulated water table heads computed over the 1989-2009 period and averaged over the entire aquifer domain at high and low resolution. It confirms results from Figure 7 and shows that the water table head is generally deeper at low resolution. However, for both resolutions, the simulated water table depth is slightly impacted when upward capillary fluxes are taken into account: it decreases by $10-20 \mathrm{~cm}$.

Figure $8 \mathrm{~b}$ shows the comparison between the simulated TWS variations ( $\triangle T$ TWS) and the GRACE estimates in terms of monthly mean annual cycles over the 2003-2009 period. The simulated $\triangle T$ TWS is computed as the sum of all land surface components from ISBA, and the river storage $(\Delta S)$ and water table $(\Delta \mathrm{H})$ variations from TRIP. The land surface components in ISBA are soil moisture $(\Delta \mathrm{W})$, vegetation interception, and snow water equivalent. Only $\Delta \mathrm{W}$ and $\Delta \mathrm{H}$ are shown in Figure $8 \mathrm{~b}$. The comparison is made in water equivalent height $(\mathrm{cm})$ and only over the groundwater domains. The NOCPL (NOCPL05) and CPL (CPLO5) $\triangle$ TWS curves are nearly superimposed in Figure 8b. Only a slight increase of the $\triangle T$ WW amplitude is found for the CPL simulation. This slight increase is mainly due to a larger amplitude in the CPL (CPL05) $\triangle W$ soil moisture signal (dashed line in Figure 8b) compared to the NOCPL (NOCPL05) $\Delta \mathrm{W}$ signal (solid line). The other components of the soil column, not shown here (snow water equivalent, vegetation, and surface storage), are not affected. Upward capillary fluxes do not introduce significant changes in the $\triangle T$ TWS signal, but they reinforce the agreement with the GRACE estimates. However, the CPLNOF and CPLNOF05 curves show larger $\triangle$ TWS amplitudes, which confirm that the absence of coupling fraction strongly increases the impact of the upward capillary fluxes. The matching 
(a) NOCPL

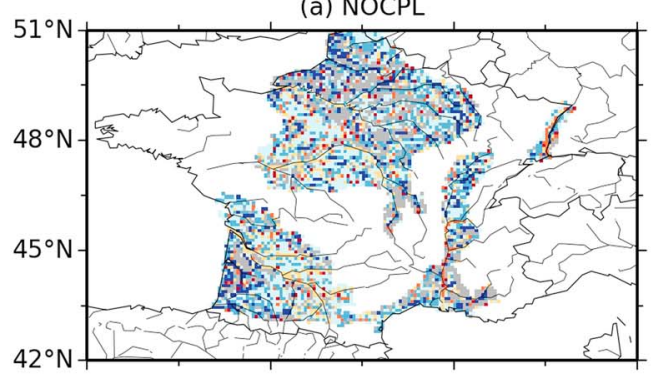

(c) CPL

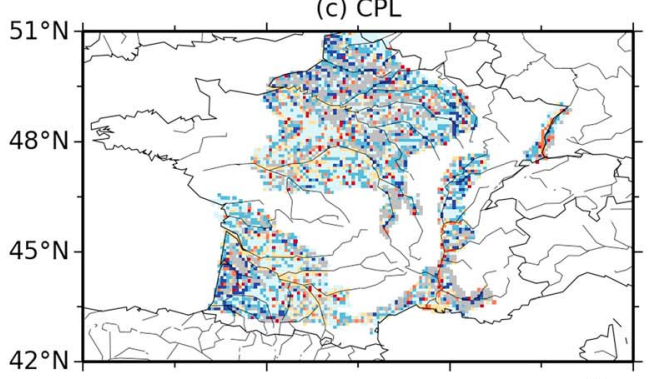

(e) CPL

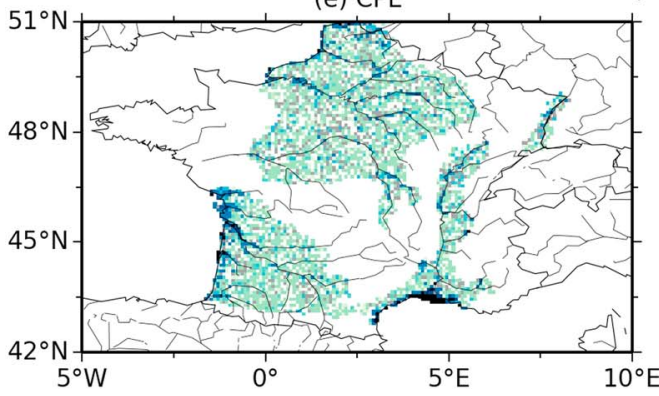

(b) NOCPL05

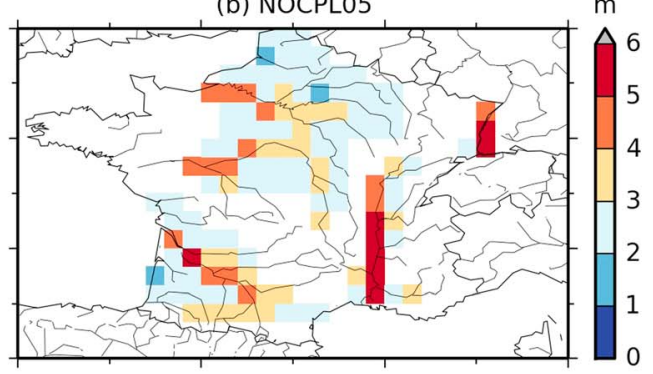

(d) CPLO5

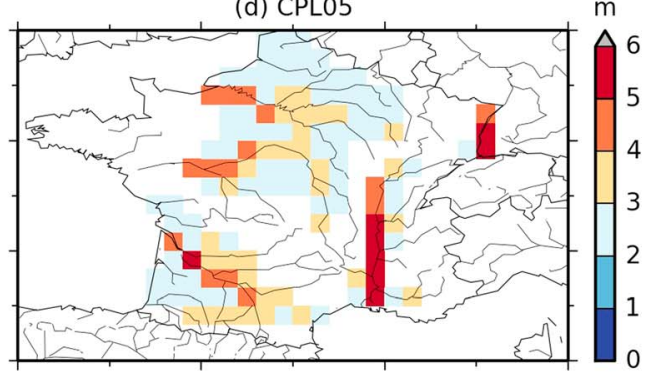

(f) CPL05

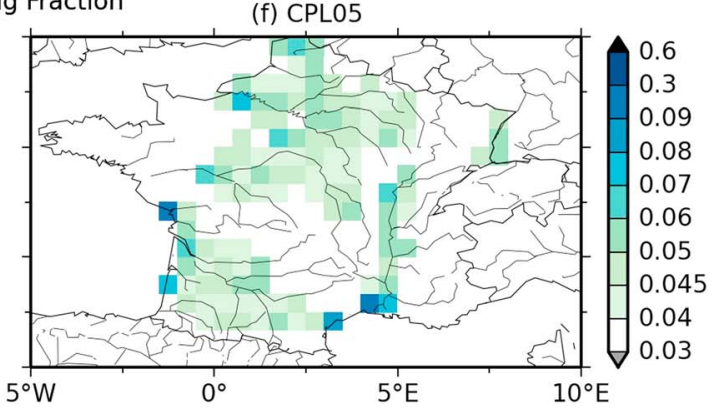

Figure 7. Temporally mean water table depth for (a) NOCPL, (b) NOCPL05, (c) CPL, and (d) CPL05. The mean fractions $f_{\text {wtd }}$ are also shown for (e) CPL and (f) CPL05. Water table depths are computed with respect to the river elevation $Z$.

between both the CPLNOF and CPLNOF05 curves with the GRACE signal seems less robust than the other experiments, which agree with the previous deteriorations found for the river discharge scores.

\subsection{Water Budget}

Figure 9 shows the mean climatological 2 m depth soil moisture profiles computed for NOCPL, CPL, NOCPL05, and CPL05 over the whole aquifer domains. Generally, upward capillary fluxes increase the soil water content for whatever the period or the domain considered, and for both high and low resolutions. During the December-February (DJF) winter period, the main impact is to moisten the lower part of the soil. This humidification spreads up to the surface during the March-May (MAM) spring period, which leads to two nearly parallel soil moisture profiles between them, while the surface layer begins to dry. During the June-August (JJA) summer period, the soil moisture of the surface layer reaches its minimum due to the ET demand from the atmosphere and the soil moisture profiles start to draw closer again.

The mean climatological ETs simulated by NOCPL and NOCPL05 in mm/day are presented in Figures 10a and $10 c$, respectively. Spatial mean values are also shown for each season. Spatial patterns are similar between the two resolutions. The maximum occurs during the JJA period and the minimum in DJF. The NOCPL05 ET mean values are slightly lower than NOCPL during the MAM and September-November (SON) periods. The differences between CPL and NOCPL and the differences between CPL05 and NOCPL05 are shown in Figures $10 \mathrm{~b}$ and $10 \mathrm{~d}$, respectively. These ET differences are computed in terms of percentage with respect to the free drain simulations. The upward capillary flux obviously affects only the aquifer domains and increases the simulated ET during each season. The maximum takes place during JJA $(+2.04 \%$ and $+0.77 \%$ on average over France, respectively) and the minimum in DJF (+0.46\% and $+0.21 \%)$. At high resolution, increase of ET 

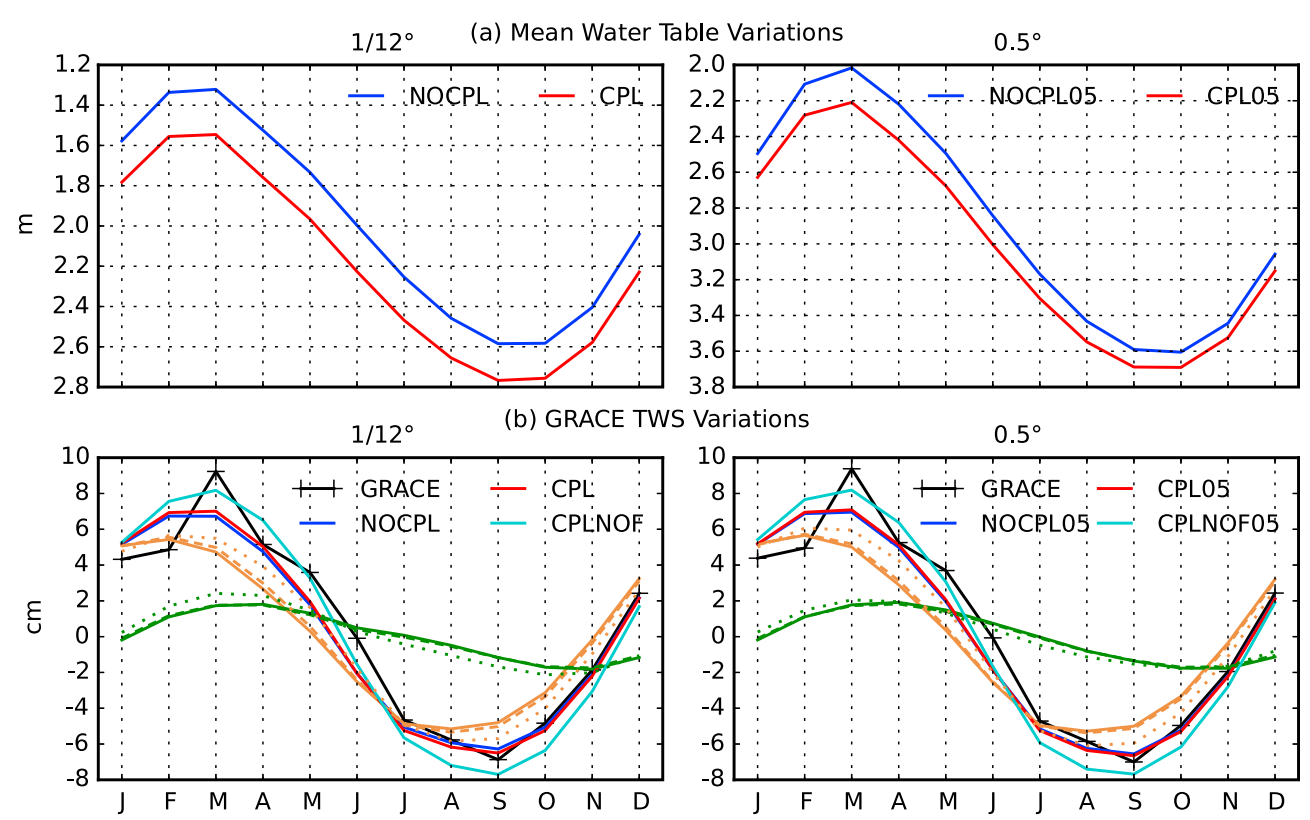

Figure 8. Monthly mean annual cycle averaged over the whole aquifer domain for (a) the water table depth variations (1989-2009 period) and (b) the simulated and GRACE-estimated TWS variations (2003-2009 period) for NOCPL, NOCPL05, CPL, CPL05, CPLNOF, and CPLNOF05. The soil moisture component $\triangle W$ (brown) and the groundwater component $\Delta H$ (green) are also shown in solid, dashed, and dotted lines for free drain, fully coupled, and no-fraction simulations, respectively. Water table depths are spatially averaged only where water table depth is lower than $6 \mathrm{~m}$ (see Figure 7c).

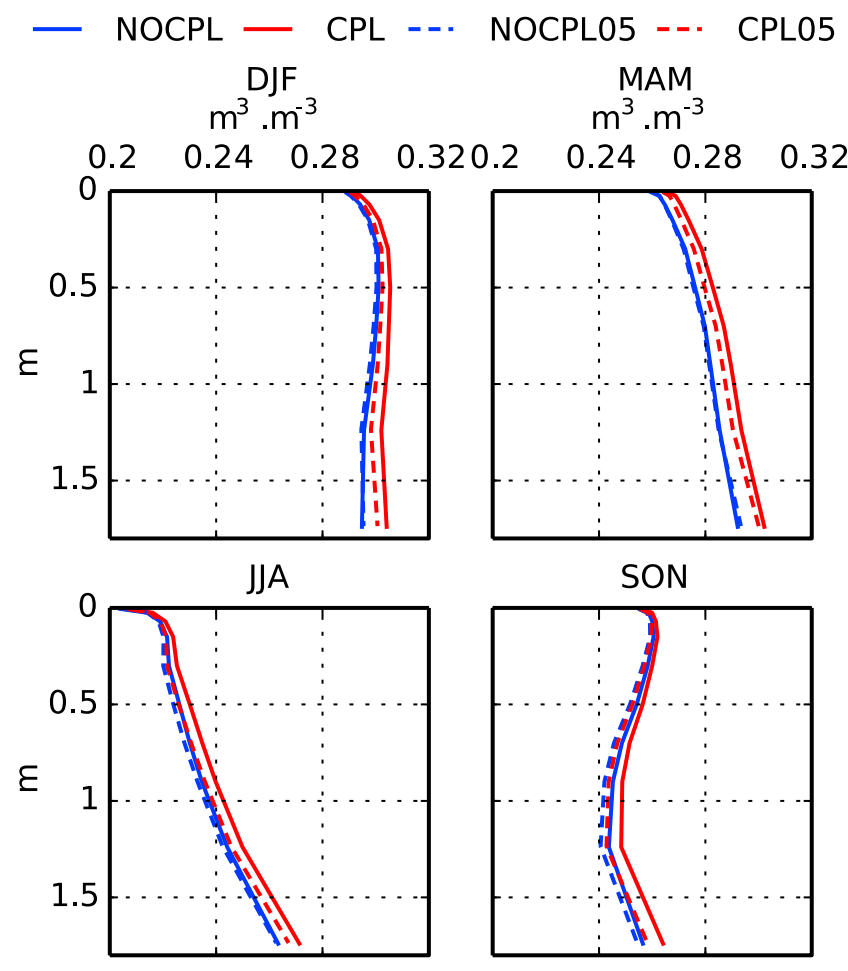

Figure 9. Mean climatological soil moisture profiles computed over the 1989-2009 period for NOCPL, NOCPL05, CPL, and CPL05 spatially averaged over the whole French aquifer domain. occurs preferentially along the rivers and in flat zones where the water table is shallow. It can exceed more than 50\% locally in the Rhone estuary or on the Landes coast. At low resolution, the spatial distribution is logically more homogeneous and no clear pattern appears. Moreover, the ET increase is twice, only half of the increase at high resolution when compared to the free drain simulations.

Figure 11 depicts the influences of upward capillary fluxes on the heat transfer from the surface to the atmosphere and its link with groundwater. The NOCPL Bowen ratios are shown in Figure 11a for each grid cell located in the aquifer domain. Driest regions correspond to higher Bowen ratio values, as is the case over the Mediterranean coast in France. The differences between CPL and NOCPL are represented in Figure $11 \mathrm{~b}$. As for the ET rates (see Figure 10b), the Bowen ratios decrease when accounting for upward capillary fluxes especially along the 
(a) NOCPL
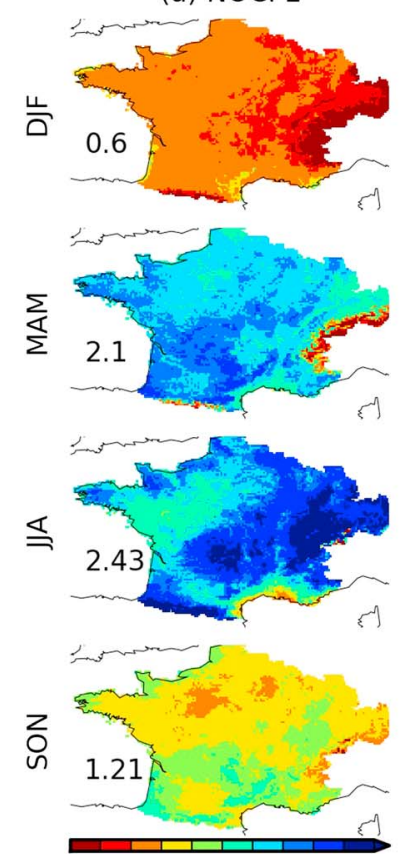

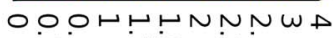
Nir Nir Nư mm.day ${ }^{-1}$
Simulated Evapotranspiration

(b) CPL-NOCPL
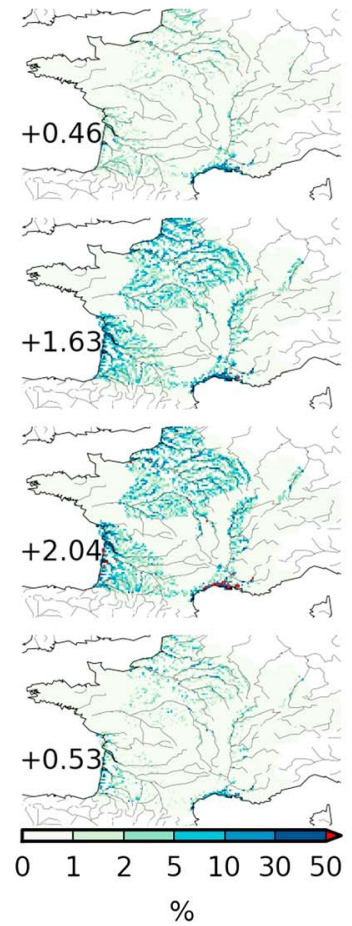

(c) NOCPL05

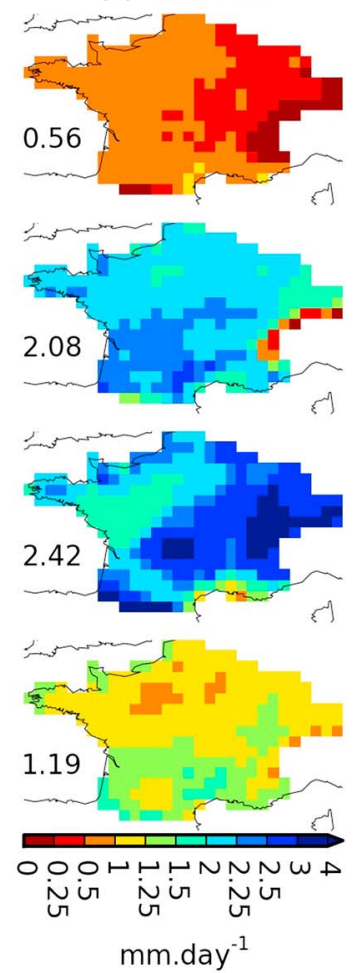

(d) CPL05-NOCPL05

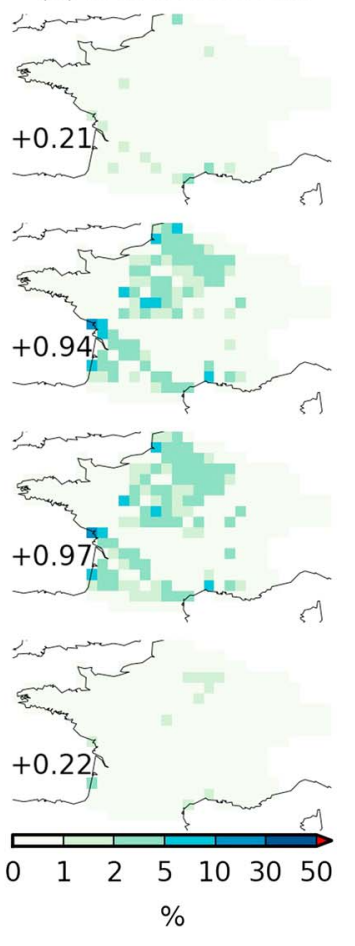

Figure 10. Mean climatological ET computed over the 1989-2009 period for (a) NOCPL and (c) NOCPL05. The differences between (b) CPL and NOCPL, and (d) CPL05 and NOCPL05 are also shown in terms of percentage with respect to NOCPL and NOCPL05, respectively.

rivers and in the flat areas. More heat is hence released in the atmosphere through latent heat flux with a fully coupled model. Moreover, the drier the region is, the more the Bowen ratio decreases.

Figure $11 \mathrm{c}$ represents the mean annual water table depth differences ( $\triangle \mathrm{WTD}$ ) between CPL and NOCPL, and Figure $11 \mathrm{~d}$ quantify the link between the Bowen ratio differences and $\triangle \mathrm{WTD}$. Each whisker in Figure 11d
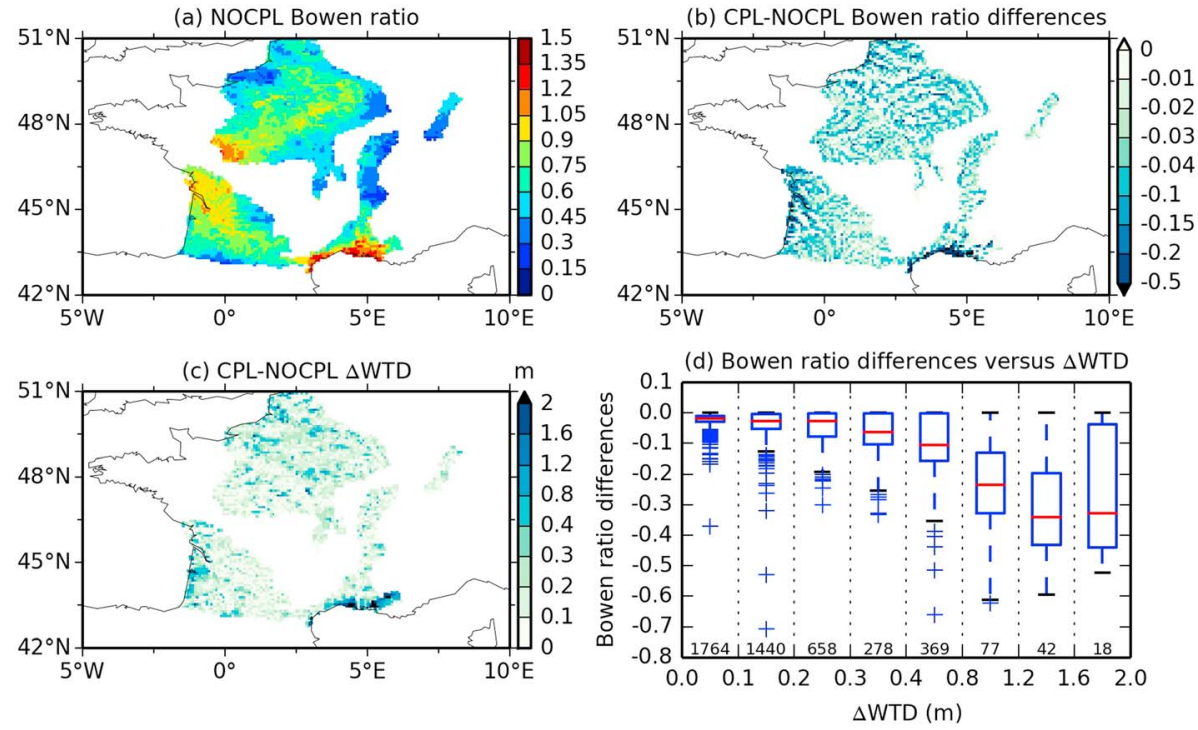

Figure 11. (a) The NOCPL Bowen ratios, (b) the Bowen ratio differences between CPL and NOCPL and (c) the water table depth differences ( $\triangle W T D$ ) between CPL and NOCPL. (d) The boxplot of the Bowen ratio differences according to their $\triangle W T D$ values is also shown. The number of grid cells is specified for each $\triangle W T D$ classes at the bottom of the boxplot. 

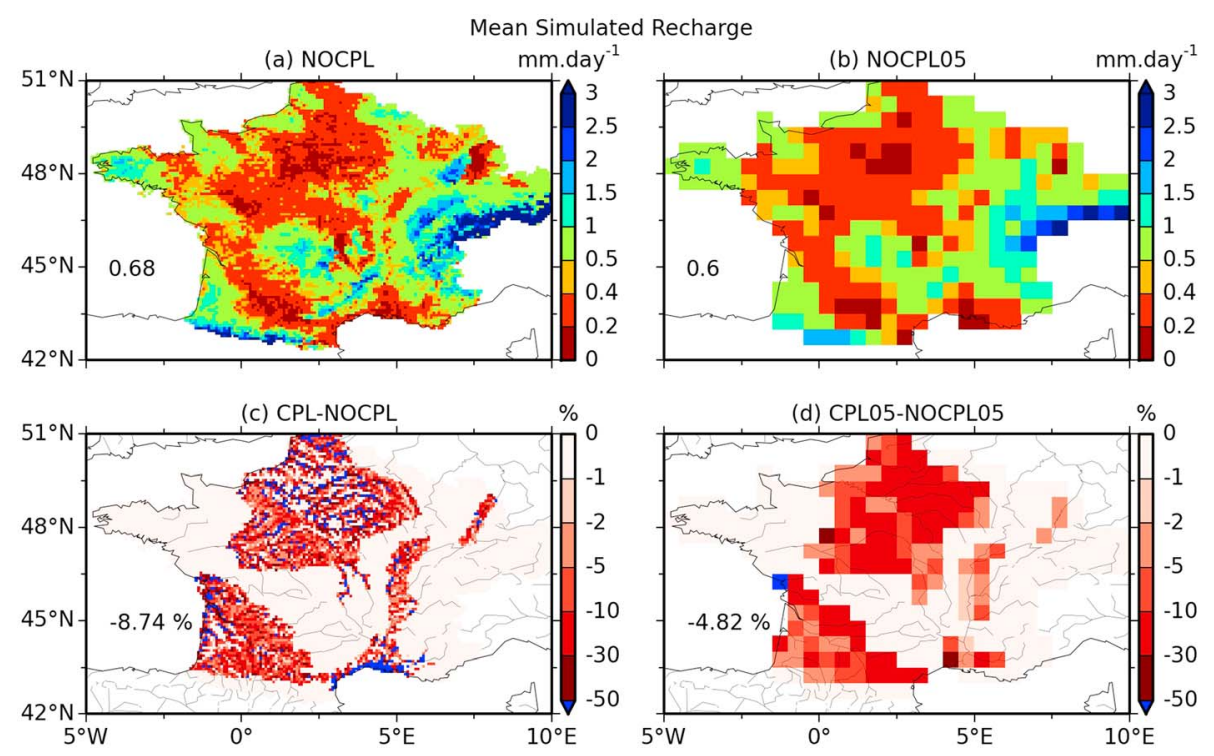

Figure 12. Spatial mean-simulated recharge calculated over the 1989-2009 period for (a) NOCPL and (b) NOCPL05. The differences between (c) CPL and NOCPL and (d) CPL05 and NOCPL05 are also shown in terms of percentage with respect to NOCPL and NOCPL05, respectively.

corresponds to the quartiles of the grid cells grouped in $\triangle \mathrm{WTD}$ subclasses. These $\triangle \mathrm{WTD}$ subclasses are shown in the abscissa of Figure 11d, and the corresponding number of grid cell is specified under each whisker. A larger decrease of the water table depth is associated to a larger decrease of the Bowen ratio. This effect is all the more important that the coupling fraction is close to 1 (see Figure 7e). This result demonstrates a connection between groundwater and surface energy fluxes that could impact the simulation of climate in Earth system modeling. Moreover, Figure 11 shows that the $\triangle$ WTD spatial variability is smoother than that of the Bowen Ratio. This emphasizes the importance of simulating groundwater lateral fluxes with a twodimensional diffusive numerical scheme, at least at high resolution, which is barely done in regional or globalscale modeling.

Figure 12 shows the spatial mean-simulated recharge computed for NOCPL and NOCPL05, which corresponds to the free gravity drainage (equation (4)). Its spatiotemporal mean values are lower at low resolution (Figure 12b) than at high resolution (Figure 12a) even though the spatial patterns are similar. The impact of the fully coupled soil bottom condition with respect to the free drain soil bottom condition is presented in Figures $12 \mathrm{c}$ and $12 \mathrm{~d}$. Recharge decreases when upward capillary fluxes are simulated. As for the ET flux, this decrease is twice as large at high resolution $(-8.21 \%)$ as it is at low resolution $(-4.79 \%)$. The spatial patterns of the mean recharge differences in Figures $12 \mathrm{c}$ and $12 \mathrm{~d}$ can be linked to the spatial patterns of the climatological ET differences in Figures $9 \mathrm{~b}$ and $9 \mathrm{c}$ : an increasing ET corresponds generally to a decreasing recharge.

Figure 13 describes the annual partition of total runoff between surface runoff and drainage for each simulation, as well as the partition of total evaporation between ground evaporation, vegetation transpiration, and canopy evaporation. All the values are expressed as the percentage of total precipitation averaged over the entire French aquifer domain and the 1989-2009 time period. The simulated annual ET is increased by $3.12 \%$ at high resolution and by $1.54 \%$ at low resolution. These results show that upward capillary fluxes have less impact on the simulated ET at low resolution than at high resolution. Plant transpiration is affected by this increase first, followed by ground evaporation. No changes occur for canopy evaporation. The simulated surface runoff is also slightly increased from about $0.5 \%$ at high resolution and $0.2 \%$ at low resolution. The simulated recharge is reduced from $2.5 \%$ and $1 \%$, respectively. This decrease in simulated recharge must be interpreted with caution, as this term regroups both upward and downward fluxes at the bottom of the ISBA soil column. Recharge is also less significant at low resolution for both the free drain and the fully coupled simulations due to a larger simulated surface runoff when compared to high resolution. A less important recharge at low resolution induces a lower water table, weaker water uptakes, 


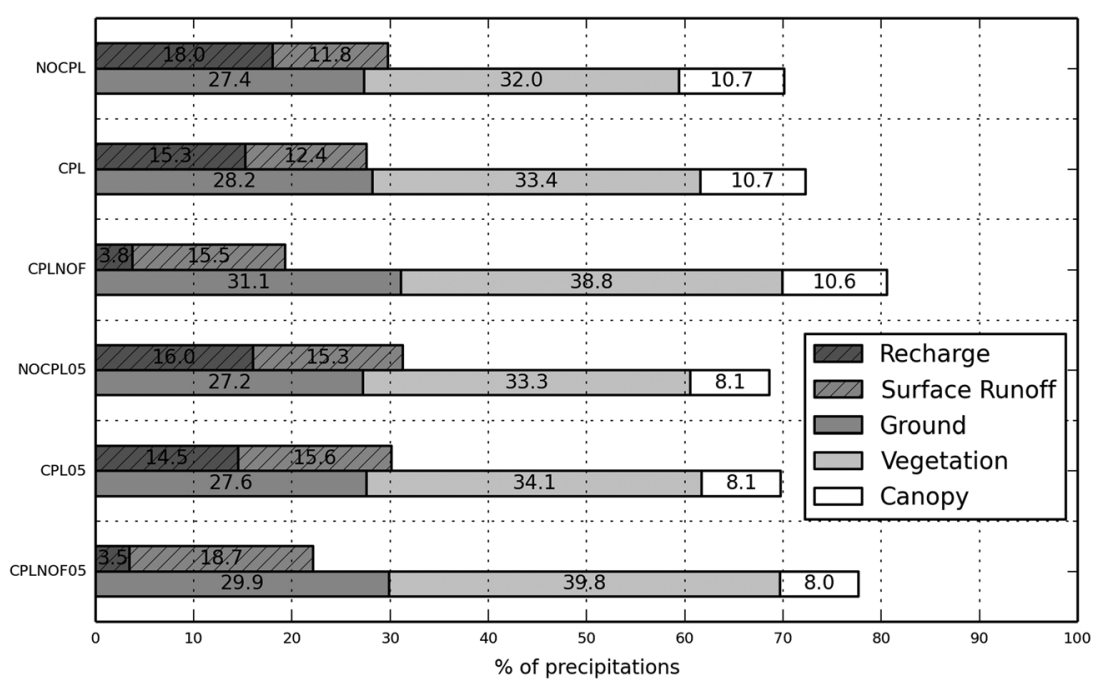

Figure 13. Histogram of the surface water budget temporally averaged on the 1989-2009 period and spatially averaged over the whole simulated aquifer domains for NOCPL, CPL, CPLNOF, NOCPL05, CPL05, and CPLNOF05. Values are given in terms of percentage of precipitations.

and hence less ET than at high resolution. These results demonstrate the need to examine the simulated surface runoff's sensitivity to the resolution in ISBA. The CPLNOF and CPLNOF05 are also shown in Figure 13. The simulated ET is increased by $10.4 \%$ (9\%) at high (low) resolution, and the simulated recharge is decreased by $14.2 \%(12.5 \%)$ at high (low) resolution when no coupling fraction is defined.

\section{Discussion}

As expected, the main impact of the capillary rise process is an increase in the simulated evapotranspiration rates. This increase reaches its maximum during the dry period (summer) and primarily affects transpiration from plants and ground evaporation. Moreover, the increase of ET varies with strong annual variations (from 2 to $5.5 \%$ at high resolution and from 0.5 to $5 \%$ at low resolution).These results agree with previous studies on the influence of groundwater on the surface water budget [Gutowski et al., 2002; Liang et al., 2003; MiguezMacho et al., 2007; Anyah et al., 2008; Sánchez-Pérez et al., 2008; Yuan et al., 2008; Guillot, 2011; Leung et al., 2011; Lo and Famiglietti, 2011]. At high resolution, the contribution of groundwater to the total ET can exceed 30\% locally during the dry period along rivers and in flat regions (Figure 10). This increase first concerns transpiration from plants, as suggested by Sánchez-Pérez et al. [2008] who conclude through an isotopic analysis conducted in the Rhine alluvial valley that the root system works as a pump, raising groundwater to the unsaturated zone by capillarity. Such values agree with the results of a recent study carried out by Guillot [2011] over the Landes of Gascony, which indicates that more than $50 \%$ of the ET could be locally imputed to root zone uptake from aquifer. Another study using a coupled atmosphere-surface-groundwater applied over a small river basin in northeastern Kansas ( 40 by $40 \mathrm{~km}^{2} ; 2-\mathrm{km}$ resolution) indicates that between 5 (wet years) and $20 \%$ (dry years) of ET is drawn from the aquifer annually [York et al., 2002].

At low resolution, Niu et al. [2007] observed an increase of between $4 \%$ and $16 \%$ in annual ET at global scale, especially over arid-to-wet transitional regions. In a more recent global-scale study from Koirala et al. [2014], global ET was increased from about 9\%. Weaker (larger) increase of ET was found in humid (arid) regions. Fluxes simulated over France were weaker than in the present study. This might be due to the use of different models and assumptions, model parameters, or input-forcing data. Simulated ET is also difficult to evaluate at these large scales because of the absence of observations. However, the good comparison between the observed and simulated river discharges suggests that these fluxes are consistent over France (see Figures 2 and 3). Moreover, the CPLNOF and CPLNOF05 simulations, which were undertaken without coupling fraction, strongly deteriorate the river discharge scores. The comparison with GRACE is also impacted (see Figure 8b). Given these results, the increases of simulated ET obtained with CPLNOF and CPLNOF05 (10.4\% rather than $3.12 \%$ for CPL and $9 \%$ rather than $1.54 \%$ for CPL05, see Figure 13) seem to be obviously excessive and 
unrealistic. Therefore, it confirms the need to take into account the spatial variability of topography inside the grid cell when simulating upward capillary fluxes at coarse resolution. It also shows the relevance of the proposed subgrid topography-based parameterization.

At last, results from Figures 7 and 11 clearly demonstrate a relationship between water table depth and surface water fluxes. A shallower water table generally increases surface latent heat flux, in particular, in driest regions. It demonstrates the relevance of taking into account groundwater in global climate models. These findings agree with several previous studies [Ferguson and Maxwell, 2010; Rihani et al., 2010; Condon et al., 2013].

This enhanced ET is associated with wetter soil induced by upward capillary fluxes from groundwater [Yuan et al., 2008]. Over France, the maximum soil water content reached in the spring is shifted by one season with respect to the ET maximum that occurs in summer (Figures 9 and 10). Thus, the upward capillary flux from the water table tends to reinforce the time lag between the simulated water content and ET [Anyah et al., 2008; Leung et al., 2011; Miguez-Macho and Fan, 2012b]. As mentioned by Miguez-Macho et al. [2007], the slowing, changing nature of the water table acts to stabilize the temporal variations in the soil moisture, giving the latter stronger seasonal persistence compared to the free drain simulation. This buffering effect was also noted in previous studies evaluating the TRIP groundwater scheme [Vergnes and Decharme, 2012; Vergnes et al., 2012].

Upward capillary fluxes limit the downward gravity drainage by providing water to the soil and hence to surface runoff and ET. As a consequence, the simulated recharge to aquifers is lower (Figure 13). As the impact is large (9\%), it is necessary to take this process into account to estimate aquifer recharge, which is a fundamental component used to force regional groundwater models in water resource management studies [Sanford, 2002]. Moreover, this lower recharge leads to a lower simulated water table, which in turn leads to lower mean river discharges by modifying the groundwater-river exchanges. A lower simulated water table reduces the gradient between the water table head $H$ and the river water level $H_{\text {riv }}$ (equation (2a)). The quantity of water transferred from the groundwater to the river is hence reduced. As a consequence, the annual mean-simulated river discharges are also reduced. This does not affect the comparison with the observations which is still good as shown in Figure 4 and Table 1.

The simulated hydrological variables compare well with the observations when accounting for upward capillary fluxes. The results of the CPLNOF and CPLNOF05 simulations show that considering upward capillary fluxes over the entire grid cell leads to an overestimation of its impact on the simulated hydrological variables. Moreover, the simulated water tables in Figure 5 agree better with the observations located near rivers. It reinforces the fact that they are mostly representative of the near-river shallow groundwater and hence confirms the need to account for the subgrid spatial topographical heterogeneity [Brutsaert and Sugita, 2008; Koirala et al., 2014]. In a previous study, Yeh and Eltahir [2005a] developed a statistical approach accounting for the subgrid spatial variability of water table dynamic and applied this parameterization with success over Illinois. Nevertheless, the authors emphasize the difficulty to apply this method at global scale since it relies on the availability of water table observations. The advantage of the present topography-based subgrid parameterization is that it depends only on elevation data sets that are easily available at larger scale.

As mentioned in section 4, upward capillary fluxes have less impact at low resolution than at high resolution. Indeed, simulated water tables located on main rivers are deeper at low resolution (Figures 7c and 7d). Deepersimulated water tables induce lower coupling fractions (Figures $7 e$ and $7 f$ ) and hence a lower impact of upward capillary fluxes at low resolution. This induces the lower values of soil moisture simulated by CPL05 compared to CPL (Figure 9), the lower ET increase found at low resolution (Figure 10), and the lower impact on recharge (Figure 12). These differences are likely due to the sensitivity of the surface runoff simulated by ISBA to the resolution. Indeed, it appears that the simulated surface runoff at low resolution is overestimated compared to that at high resolution (Figure 13). This diminishes the recharge and lowers the water table. With a free drain soil bottom condition, it induces drier soil and a lower ET (Figures 10a and 10c). With a fully coupled soil bottom condition, the simulated fraction of upward capillary fluxes as well as the ET are reduced (Figures 10b and 10d) due to the lower water table. These results demonstrate an important sensitivity to the resolution of the simulated surface runoff which has not yet been fully understood. This sensitivity could be linked to the TOPMODEL parameterization used in conjunction with the diffusive soil scheme of ISBA [Decharme et al., 2013].

Other reasons can be invoked to explain the lower impact of the upward capillary fluxes at low resolution. First, uncertainties remain concerning the specific river elevation $Z$ chosen to compute the water table depth 
$Z_{T}$ inside each large grid cell (equation (5)). This elevation gives the best results for constructing the hydrological network at $1 / 12^{\circ}$ and allows us to consider it as representative of the mean elevation of the rivers inside a $1 / 12^{\circ}$ resolution cell [Vergnes et al., 2012]. However, this choice is tainted by uncertainties arising from the spatial heterogeneity of the 30 arc second resolution elevation inside each grid cell and from the 30 arc second elevation itself. These uncertainties are reinforced at low resolution by the more complex hydrological network inside each coarser grid cell. Second, water table depths are strongly constrained by the simulated river stage elevation in the grid cell and hence depend on the TRIP river geometry. In particular, the river bankfull height $h_{c}$ [Decharme et al., 2012] appears to be an important parameter for simulating water table depth. Even though $h_{c}$ was determined from observation-based geomorphological relationships (equation (9c)), it is still a conceptual approach with a simplified representation of reality. Moreover, the larger size and the limited number of aquifer cells at low resolution make the aquifer system more sensitive to the larger values of $h_{c}$ than at high resolution. However, such affirmation may not be important for global climate applications considering the relatively small size of the French watershed compared to the main watershed at the global scale. At last, basin-scale fine-tuned calibrations of the groundwater-related parameters could surely improve the comparison with observations. However, such tuning could compensate for some errors in the prescribed atmospheric forcing or some uncertainties due to the absence of hydrological processes, such as floods, pumping, or dams. The determination of the fraction $f_{\text {wtd }}$ is also questionable since it depends directly on the 30 arc second elevation and its associated uncertainties.

\section{Conclusion}

In this study, the groundwater scheme introduced in the TRIP river-routing model and evaluated with success over France in Vergnes et al. [2012] was coupled with the ISBA land surface model using a multilayer soil diffusion scheme in order to take into account the upward capillary fluxes from the water table to the overlying unsaturated zone of the soil. An original parameterization based on a coupling grid cell fraction dependent on subgrid topography has been proposed to simulate these upward capillary fluxes only where they are supposed to occur in the coarse resolution grid cell. New geomorphological relationships based on observations were introduced to compute the river geometry parameters. An initial control experiment without groundwater uptake was compared to a second fully coupled simulation over the 1989-2009 period using the SAFRAN meteorological analysis over France.

The results found in this study confirm the nonnegligible impact of groundwater on the simulated water budget. Introducing upward capillary fluxes from the groundwater into the ISBA soil column increases the simulated ET. This increase is especially apparent during the dry summer period. It also enhances the soil moisture content and contributes to the introduction of more memory into the system. Alongside these effects, surface runoff increases, while recharge from ISBA to the groundwater scheme becomes lower. This results in a lower simulated water table when upward capillary fluxes are taken into account, such decrease being reduced where lateral groundwater fluxes are large enough. Until now, this process has not usually been taken into account in hydrogeological models, although it can have a large impact locally, and this impact might be strengthened in the context of climate change. The simulated river discharges and water table heads still compare well with observations when the coupling is activated. This confirms the importance of considering the subgrid spatial variability of topography inside the coarse resolution grid cells when simulating upward capillary fluxes only on alluvial plains. This statement is reinforced by the poor results obtained with the sensitivity experiments performed without this parameterization. Water capillary rises have a less-pronounced impact on the simulated water budget at low resolution than at high resolution. These differences are located mostly on the main rivers. The overestimated surface runoff at low resolution is suspected to be responsible of these differences. This overestimation is likely due to deficiencies in the TOPMODEL parameterization used in ISBA to generate surface runoff. This problem will be further investigated in a future version of ISBA. In addition to the uncertainties due to some parameters used by TRIP, as previously discussed (elevation, river geometry, etc.), uncertainties in precipitation forcing used to drive ISBA can also be a source of errors capable of changing the resulting hydrological responses [Decharme and Douville, 2006; Szczypta et al., 2011; Vergnes and Decharme, 2012].

Future work will focus on the impact of upward capillary fluxes at the global scale following the work initiated in Vergnes and Decharme [2012] in order to confirm the results obtained over France. The ultimate objective 
(a) $W=f\left(Q_{m}\right)$

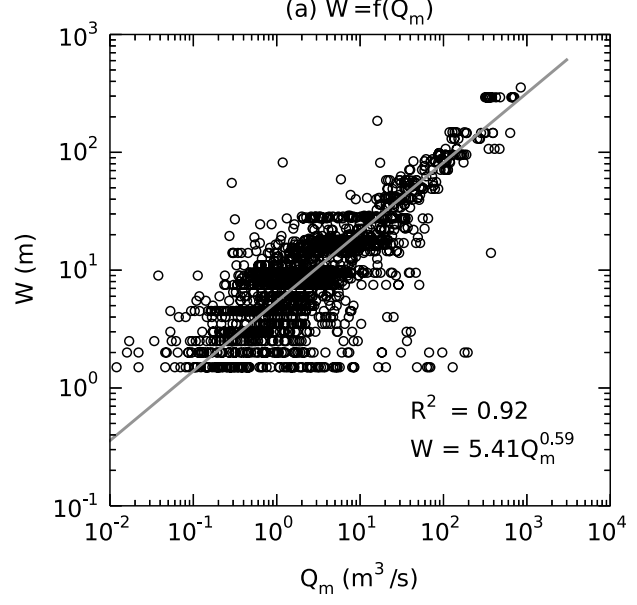

(b) $h_{c}=f\left(Q_{m}\right)$

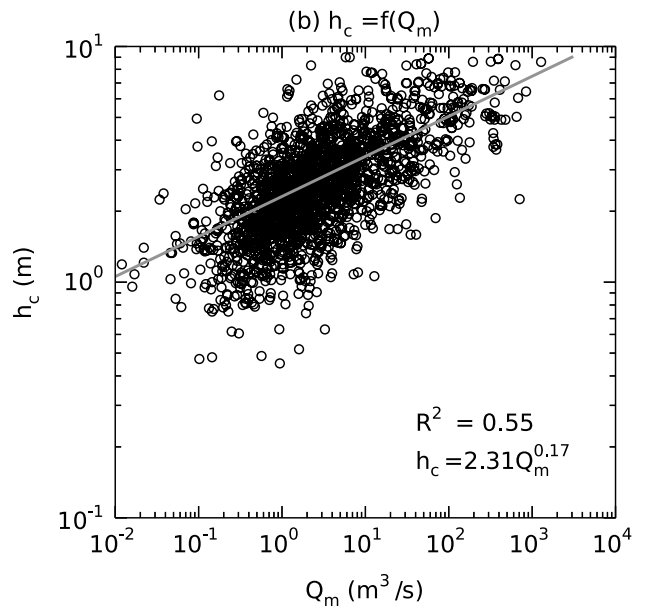

Figure A1. (a) Regression obtained between the observed annual mean river discharges $Q_{m}$ and the river widths of the SYRAH database and (b) the regression between the observed maximum water height, supposed to be equal to $h_{c}$ and the observed mean river discharges. The correlation coefficients and the corresponding equations are also given.

will be to introduce the fully coupled system including groundwater into the CNRM global climate model [Voldoire et al., 2013] in order to assess the importance of groundwater processes to the simulations of both recent and future climates.

\section{Appendix A: Geomorphological Relationships}

Observed mean river discharges and maximum water heights were selected from 1873 gauging stations available over France. River widths were determined from the "SYstème Relationnel d'Audit de I'Hydromorphologie des Cours d'Eau" (SYRAH) database [Chandesris et al., 2009] at each river gauging station. Figure A1a shows the regression obtained between the observed mean river discharges from the BD Hydro (http://www.hydro.eaufrance.fr) and the SYRAH river widths. It corresponds to the first geomorphological relationship linking the river width $W$ and the mean river discharge $Q_{m}$ (see equation (9a)). In the same way, Figure $\mathrm{A} 1 \mathrm{~b}$ shows the regression between the observed mean river discharges and the observed maximum river water levels. The maximum water level measured for a gauging station generally corresponds to the maximum of the river staff gauge. Therefore, it can be assumed equal to the river bankfull height $h_{c}$. It gives a second relationship linking $h_{c}$ and $Q_{m}$ (see equation (9b)). The combination of these relationships yields a third relationship which can then be used to determine $h_{c}$ from $W$ (equation (9c)).

\section{Acknowledgments}

This work was supported by the French "Office National de l'Eau et des Milieux Aquatiques" (ONEMA), the "Centre National de Recherches Météorologiques" (CNRM) of Météo-France, and the "Centre National de la Recherche Scientifique" (CNRS) of the French research ministry. Discharge observations and river levels were provided by the French Hydro database (Ministère de l'écologie; http:// www.eaufrance.fr) and water table head observations by the ADES database (Ministère de l'écologie; http://www. ades.eaufrance.fr). GRACE land data were processed by Sean Swenson, supported by the NASA MEASURES Program, and are available at http://grace.jpl.nasa.gov.

\section{References}

Alkama, R., B. Decharme, H. Douville, M. Becker, A. Cazenave, J. Sheffield, A. Voldoire, S. Tyteca, and P. Le Moigne (2010), Global evaluation of the ISBA-TRIP continental hydrological system. Part I: Comparison to GRACE terrestrial water storage estimates and in situ river discharges, J. Hydrometeorol., 11(3), 583-600, doi:10.1175/2010JHM1211.1.

Anyah, R. O., C. P. Weaver, G. Miguez-Macho, Y. Fan, and A. Robock (2008), Incorporating water table dynamics in climate modeling: 3. Simulated groundwater influence on coupled land-atmosphere variability, J. Geophys. Res., 113, D07103, doi:10.1029/2007JD009087. Bartholomé, E., and A. S. Belward (2005), GLC2000: A new approach to global land cover mapping from Earth observation data, Int. J. Remote Sens., 26(9), 1959-1977, doi:10.1080/01431160412331291297.

Berti, W., et al. (2003), Instrument of GRACE-GPS augments gravity measurements, GPS World, 14(2), 16-29.

Bierkens, M. F. P., and B. J. J. M. van den Hurk (2007), Groundwater convergence as a possible mechanism for multi-year persistence in rainfall, Geophys. Res. Lett., 34, L02402, doi:10.1029/2006GL028396.

Boone, A., V. Masson, T. Meyers, and J. Noilhan (2000), The influence of the inclusion of soil freezing on simulations by a soil-vegetationatmosphere transfer scheme, J. Appl. Meteorol., 39(9), 1544-1569, doi:10.1175/1520-0450(2000)039<1544:TIOTIO<2.0.CO;2.

Braud, I., N. Varado, and A. Olioso (2005), Comparison of root water uptake modules using either the surface energy balance or potential transpiration, J. Hydrol., 301(1-4), 267-286, doi:10.1016/j.jhydrol.2004.06.033.

Brutsaert, W., and M. Sugita (2008), Is Mongolia's groundwater increasing or decreasing?, The case of the Kherlen River basin/Les eaux souterraines de Mongolie s'accroissent ou décroissent-elles?, Cas du bassin versant la Rivière Kherlen, Hydrol. Sci. J., 53(6), 1221-1229, doi:10.1623/hysj.53.6.1221.

Canadell, J., R. B. Jackson, J. B. Ehleringer, H. A. Mooney, O. E. Sala, and E.-D. Schulze (1996), Maximum rooting depth of vegetation types at the global scale, Oecologia, 108(4), 583-595, doi:10.1007/BF00329030.

Chandesris, A., N. Mengin, J. R. Maiavoi, Y. Souchon, and J. G. Wasson (2009), SYstème Relationnel d'Audit de I'Hydromorphologie des Cours d'Eau SYRAH-CE, Large scale Atlas V2.0, IRSTEA Eaux. 
Condon, L. E., R. M. Maxwell, and S. Gangopadhyay (2013), The impact of subsurface conceptualization on land energy fluxes, Adv. Water Resour., 60, 188-203, doi:10.1016/j.advwatres.2013.08.001.

Crowley, J. W., J. X. Mitrovica, R. C. Bailey, M. E. Tamisiea, and J. L. Davis (2006), Land water storage within the Congo Basin inferred from GRACE satellite gravity data, Geophys. Res. Lett., 33, L19402, doi:10.1029/2006GL027070.

Decharme, B., and H. Douville (2006), Uncertainties in the GSWP-2 precipitation forcing and their impacts on regional and global hydrological simulations, Clim. Dyn., 27(7), 695-713, doi:10.1007/s00382-006-0160-6.

Decharme, B., R. Alkama, H. Douville, M. Becker, and A. Cazenave (2010), Global evaluation of the ISBA-TRIP continental hydrological system. Part II: Uncertainties in river routing simulation related to flow velocity and groundwater storage, J. Hydrometeorol., 11(3), 601-617, doi:10.1175/2010JHM1212.1.

Decharme, B., A. Boone, C. Delire, and J. Noilhan (2011), Local evaluation of the interaction between soil biosphere atmosphere soil multilayer diffusion scheme using four pedotransfer functions, J. Geophys. Res., 116, D20126, doi:10.1029/2011JD016002.

Decharme, B., R. Alkama, F. Papa, S. Faroux, H. Douville, and C. Prigent (2012), Global off-line evaluation of the ISBA-TRIP flood model, Clim. Dyn., 38(7), 1389-1412, doi:10.1007/s00382-011-1054-9.

Decharme, B., E. Martin, and S. Faroux (2013), Reconciling soil thermal and hydrological lower boundary conditions in land surface models, J. Geophys. Res. Atmos., 118, 7819-7834, doi:10.1002/jgrd.50631.

Durand, Y., E. Brun, L. Mérindol, G. Guyomarc'h, B. Lesaffre, and E. Martin (1993), A meteorological estimation of relevant parameters for snow models, Ann. Glaciol., 18, 65-71.

Fan, Y., G. Miguez-Macho, C. P. Weaver, R. Walko, and A. Robock (2007), Incorporating water table dynamics in climate modeling: 1. Water table observations and equilibrium water table simulations, J. Geophys. Res., 112, D10125, doi:10.1029/2006JD008111.

Faroux, S., A. T. Kaptué Tchuenté, J.-L. Roujean, V. Masson, E. Martin, and P. Le Moigne (2013), ECOCLIMAP-II/Europe: A twofold database of ecosystems and surface parameters at $1 \mathrm{~km}$ resolution based on satellite information for use in land surface, meteorological and climate models, Geosci. Model Dev., 6(2), 563-582, doi:10.5194/gmd-6-563-2013.

Ferguson, I. M., and R. M. Maxwell (2010), Role of groundwater in watershed response and land surface feedbacks under climate change, Water Resour. Res., 46, W00F02, doi:10.1029/2009WR008616.

Guillot, M. (2011), Analyse rétrospective des relations nappe-végétation de sous-bassins versants forestiers de la rivière Leyre, Bordeaux 1 , 8 December.

Gutowski, W. J. G., C. J. Vörösmarty, M. Person, Z. Ötles, B. Fekete, and J. York (2002), A Coupled Land-Atmosphere Simulation Program (CLASP): Calibration and validation, J. Geophys. Res., 107(D16), 4283, doi:10.1029/2001JD000392.

Jiang, X., G.-Y. Niu, and Z.-L. Yang (2009), Impacts of vegetation and groundwater dynamics on warm season precipitation over the Central United States, J. Geophys. Res., 114, D06109, doi:10.1029/2008JD010756.

Koirala, S., P. J.-F. Yeh, Y. Hirabayashi, S. Kanae, and T. Oki (2014), Global-scale land surface hydrologic modeling with the representation of water table dynamics, J. Geophys. Res. Atmos., 119, 75-89, doi:10.1002/2013JD020398.

Lam, A., D. Karssenberg, B. J. J. M. van den Hurk, and M. F. P. Bierkens (2011), Spatial and temporal connections in groundwater contribution to evaporation, Hydrol. Earth Syst. Sci., 15(8), 2621-2630, doi:10.5194/hess-15-2621-2011.

Leung, L., M. Huang, Y. Qian, and X. Liang (2011), Climate-soil-vegetation control on groundwater table dynamics and its feedbacks in a climate model, Clim. Dyn., 36(1), 57-81, doi:10.1007/s00382-010-0746-x.

Levine, J. B., and G. D. Salvucci (1999), Equilibrium analysis of groundwater-vadose zone interactions and the resulting spatial distribution of hydrologic fluxes across a Canadian Prairie, Water Resour. Res., 35(5), 1369-1383, doi:10.1029/1999WR900018.

Liang, X., Z. Xie, and M. Huang (2003), A new parameterization for surface and groundwater interactions and its impact on water budgets with the variable infiltration capacity (VIC) land surface model, J. Geophys. Res., 108(D16), 8613, doi:10.1029/2002JD003090.

Lo, M.-H., and J. S. Famiglietti (2011), Precipitation response to land subsurface hydrologic processes in atmospheric general circulation model simulations, J. Geophys. Res., 116, D07103, doi:10.1029/2010JD015134.

Lo, M.-H., J. S. Famiglietti, P. J.-F. Yeh, and T. H. Syed (2010), Improving parameter estimation and water table depth simulation in a land surface model using GRACE water storage and estimated base flow data, Water Resour. Res., 46, W05517, doi:10.1029/2009WR007855.

Lyon, S. W., et al. (2008), Coupling terrestrial and atmospheric water dynamics to improve prediction in a changing environment, Bull. Am. Meteorol. Soc., 89(9), 1275-1279, doi:10.1175/2008BAMS2547.1.

Masson, V., et al. (2013), The SURFEXv7.2 land and ocean surface platform for coupled or offline simulation of Earth surface variables and fluxes, Geosci. Model Dev., 6(4), 929-960, doi:10.5194/gmd-6-929-2013.

Maxwell, R. M., and N. L. Miller (2005), Development of a coupled land surface and groundwater model, J. Hydrometeorol., 6(3), 233-247, doi:10.1175/JHM422.1.

Maxwell, R. M., J. K. Lundquist, J. D. Mirocha, S. G. Smith, C. S. Woodward, and A. F. B. Tompson (2010), Development of a coupled groundwater-atmosphere model, Mon. Weather Rev., 139(1), 96-116, doi:10.1175/2010MWR3392.1.

Miguez-Macho, G., and Y. Fan (2012a), The role of groundwater in the Amazon water cycle: 1. Influence on seasonal streamflow, flooding and wetlands, J. Geophys. Res., 117, D15113, doi:10.1029/2012JD017539.

Miguez-Macho, G., and Y. Fan (2012b), The role of groundwater in the Amazon water cycle: 2. Influence on seasonal soil moisture and evapotranspiration, J. Geophys. Res., 117, D15114, doi:10.1029/2012JD017540.

Miguez-Macho, G., Y. Fan, C. P. Weaver, R. Walko, and A. Robock (2007), Incorporating water table dynamics in climate modeling: 2. Formulation, validation, and soil moisture simulation, J. Geophys. Res., 112, D13108, doi:10.1029/2006JD008112.

Nash, J. E., and J. V. Sutcliffe (1970), River flow forecasting through conceptual models part I-A discussion of principles, J. Hydrol., 10(3), 282-290, doi:10.1016/0022-1694(70)90255-6.

Niu, G.-Y., Z.-L. Yang, R. E. Dickinson, L. E. Gulden, and H. Su (2007), Development of a simple groundwater model for use in climate models and evaluation with Gravity Recovery and Climate Experiment data, J. Geophys. Res., 112, D07103, doi:10.1029/2006JD007522.

Quintana-Seguí, P., P. Le Moigne, Y. Durand, E. Martin, F. Habets, M. Baillon, C. Canellas, L. Franchisteguy, and S. Morel (2008), Analysis of nearsurface atmospheric variables: Validation of the SAFRAN analysis over France, J. Appl. Meteorol. Climatol., 47(1), 92-107, doi:10.1175/ 2007JAMC1636.1.

Rihani, J. F., R. M. Maxwell, and F. K. Chow (2010), Coupling groundwater and land surface processes: Idealized simulations to identify effects of terrain and subsurface heterogeneity on land surface energy fluxes, Water Resour. Res., 46, W12523, doi:10.1029/2010WR009111.

Salvucci, G. D., and D. Entekhabi (1995), Hillslope and climatic controls on hydrologic fluxes, Water Resour. Res., 31(7), 1725-1739, doi:10.1029/95WR00057.

Sánchez-Pérez, J. M., E. Lucot, T. Bariac, and M. Trémolières (2008), Water uptake by trees in a riparian hardwood forest (Rhine floodplain, France), Hydrol. Process., 22(3), 366-375, doi:10.1002/hyp.6604.

Sanford, W. (2002), Recharge and groundwater models: An overview, Hydrogeol. J., 10(1), 110-120, doi:10.1007/s10040-001-0173-5. 
Schmidt, R., et al. (2006), GRACE observations of changes in continental water storage, Global Planet. Change, 50(1-2), 112-126, doi:10.1016/ j.gloplacha.2004.11.018.

Seo, K.-W., C. R. Wilson, J. S. Famiglietti, J. L. Chen, and M. Rodell (2006), Terrestrial water mass load changes from Gravity Recovery and Climate Experiment (GRACE), Water Resour. Res., 42, W05417, doi:10.1029/2005WR004255.

Swenson, S., and J. Wahr (2006), Post-processing removal of correlated errors in GRACE data, Geophys. Res. Lett., 33, L08402, doi:10.1029/ 2005 GL025285.

Swenson, S., J. Wahr, and P. C. D. Milly (2003), Estimated accuracies of regional water storage variations inferred from the Gravity Recovery and Climate Experiment (GRACE), Water Resour. Res., 39(8), 1223, doi:10.1029/2002WR001808.

Syroka, J., and R. Toumi (2001), Scaling and persistence in observed and modeled surface temperature, Geophys. Res. Lett., 28(17), 3255-3258, doi:10.1029/2000GL012273.

Szczypta, C., J.-C. Calvet, C. Albergel, G. Balsamo, S. Boussetta, D. Carrer, S. Lafont, and C. Meurey (2011), Verification of the new ECMWF ERA-Interim reanalysis over France, Hydrol. Earth Syst. Sci., 15(2), 647-666, doi:10.5194/hess-15-647-2011.

Tapley, B. D., S. Bettadpur, J. C. Ries, P. F. Thompson, and M. M. Watkins (2004), GRACE measurements of mass variability in the Earth system, Science, 305(5683), 503-505, doi:10.1126/science.1099192.

Tóth, J. (1963), A theoretical analysis of groundwater flow in small drainage basins, J. Geophys. Res., 68(16), 4795-4812, doi:10.1029/ JZ068i016p04795.

Van den Hurk, B., et al. (2005), Soil control on runoff response to climate change in regional climate model simulations, J. Clim., 18(17), 3536-3551, doi:10.1175/JCLI3471.1.

Vergnes, J.-P., and B. Decharme (2012), A simple groundwater scheme in the TRIP river routing model: global off-line evaluation against GRACE terrestrial water storage estimates and observed river discharges, Hydrol. Earth Syst. Sci., 16(10), 3889-3908, doi:10.5194/hess-163889-2012.

Vergnes, J.-P., B. Decharme, R. Alkama, E. Martin, F. Habets, and H. Douville (2012), A simple groundwater scheme for hydrological and climate applications: description and offline evaluation over France, J. Hydrometeorol., 13(4), 1149-1171, doi:10.1175/JHM-D-11-0149.1.

Voldoire, A., et al. (2013), The CNRM-CM5.1 global climate model: Description and basic evaluation, Clim. Dyn., 40(9-10), 2091-2121, doi:10.1007/s00382-011-1259-y.

Wahr, J., S. Swenson, V. Zlotnicki, and I. Velicogna (2004), Time-variable gravity from GRACE: First results, Geophys. Res. Lett., 31, L11501, doi:10.1029/2004GL019779.

Weisheimer, A., F. J. Doblas-Reyes, T. Jung, and T. N. Palmer (2011), On the predictability of the extreme summer 2003 over Europe, Geophys. Res. Lett., 38, L05704, doi:10.1029/2010GL046455.

Yeh, P. J.-F., and E. A. B. Eltahir (2005a), Representation of water table dynamics in a land surface scheme. Part Il: Subgrid variability, J. Clim., 18(12), 1881-1901, doi:10.1175/JCLI3331.1.

Yeh, P. J.-F., and E. A. B. Eltahir (2005b), Representation of water table dynamics in a land surface scheme. Part I: Model development, J. Clim., 18(12), 1861-1880, doi:10.1175/JCLI3330.1.

Yeh, P. J.-F., and J. S. Famiglietti (2009), Regional groundwater evapotranspiration in Illinois, J. Hydrometeorol., 10(2), 464-478, doi:10.1175/ 2008JHM1018.1.

Yeh, P. J.-F., M. Irizarry, and E. A. B. Eltahir (1998), Hydroclimatology of Illinois: A comparison of monthly evaporation estimates based on atmospheric water balance and soil water balance, J. Geophys. Res., 103(D16), 19,823-19,837, doi:10.1029/98JD01721.

York, J. P., M. Person, W. J. Gutowski, and T. C. Winter (2002), Putting aquifers into atmospheric simulation models: An example from the Mill Creek Watershed, northeastern Kansas, Adv. Water Resour., 25(2), 221-238, doi:10.1016/S0309-1708(01)00021-5.

Yuan, X., Z. Xie, J. Zheng, X. Tian, and Z. Yang (2008), Effects of water table dynamics on regional climate: A case study over east Asian monsoon area, J. Geophys. Res., 113, D21112, doi:10.1029/2008JD010180. 